\title{
Sinemadaki Teknik Gelișmeler Ișığında Plan-Sekansın Film Biçemine Etkileri Üzerine Bir İnceleme: 1917 Örneği
}

\author{
Ahmet Nafiz KAVi' ${ }^{12}$ \\ Mehtap KAVi ${ }^{3}$
}

\begin{abstract}
Öz
Bu çalışmanın amacı sinemada kullanılan teknolojik araç-gereç ve buna bağlı olarak gelişen tekniklerin, plan-sekans kullanımını nasıl etkilediğini ve bunun film diline yansımalarını incelemektir. Çalışmada 1917 filmi üzerinden, sinemadaki teknolojik gelişmelerin bu tekniğin uygulanmasına sunduğu katkılar ortaya konmuş ve bu doğrultuda plan-sekans'ın film biçemine etkileri betimleyici yöntem ile analiz edilmiştir.

Teknolojik gelişmelerin sinema tekniğine sunduğu imkanlar sayesinde, plan-sekans çekimlerin ve bunların birleştirilerek tek plan gibi görünen filmlerin üretiminin eskiye nazaran kolaylaştığı görülmüştür. Sonuç olarak tek plan gibi görünen filmlerin yeni teknikler sayesinde belli oranda kurgulanabildiği ve bu sayede yönetmenin film biçemi üzerindeki kontrolünü koruduğu ortaya konmuştur.
\end{abstract}

Anahtar Kelimeler: 1917, Plan-sekans, Tek çekim, Uzun Çekim, Kurgu.

Atıf (Cite as): Kavi, A. N. \& Kavi, M. (2020). Sinemadaki Teknik Gelișmeler Ișığında Plan-Sekansın Film Biçemine Etkileri Üzerine Bir İnceleme: 1917 Örneği. Akdeniz Üniversitesi İletișim Fakültesi Dergisi, 34, 11-44. D0I: 10.31123/akil.781856.

1 Öğr. Gör., Uşak Üniversitesi, Sosyal Bilimler Meslek Yüksekokulu, ahmet.kavi@usak.edu.tr, ORCID Numarası: 0000-0003-3728-0301.

2 Sorumlu Yazar (Corresponding Author)

3 Yüksek Lisans Öğrencisi, Uşak Üniversitesi, Lisansüstü Eğitim Enstitüsü, İletişim Bilimleri, kavi.mehtap@gmail. com, ORCID Numarasi: 0000000208302594. 


\title{
A Study on the Effects of Plan-Sequence on Film Style in the Light of Technical Developments in Cinema: The Case of 1917
}

\begin{abstract}
The aim of this study is to examine how technological equipment and techniques used in cinema affect the use of plan-sequence and its reflections on film language. In the study, the contributions of technological developments in cinema to the application of this technique were revealed through the film named 1917. Accordingly, the effects of plan-sequence on the film style were analyzed with a descriptive method.

With the possibilities offered by the technological developments to the cinema technique, it has been observed that the production of plan-sequence shooting and the films that look like a single plan by combining them have become easier than before. As a result, it has been revealed that films that seem like a single plan can be edited to a certain extent thanks to new techniques and thus the director preserves his control over the film style.
\end{abstract}

Keywords: 1917, Plan-sequénce, One-shot, Long take, Editing.

\section{Giriș}

Plan-sekansın sinemada anlatım biçimine katkıda bulunacak bir yöntem olarak denenmesinin uzunca bir tarihi olmasına rağmen, son yıllarda gerçekleşen teknolojik gelişmeler bu tekniğin yeni uygulamaları yönetmenlere cesaret vermektedir. Geçmişteki en popüler ve ilk örneklerinden biri olan Hitchcock'un Rope (1948) filminde tüm filmin kesintisiz bir tek planda çekilmiş izlenimi yaratılma çabası (Monaco, 2001: 127), dönemin teknik koşulları içerisinde başarılı bir örnek olarak kabul edilmektedir. Fakat planlama-hazırlık ve çekim sırasındaki zorluklar göz önünde bulundurulduğunda, plan-sekansın yaygın bir kullanımına rastlamak pek mümkün değildir. Hem oyuncular, hem de teknik ekibi zorlayan birçok neden yüzünden maceralı bir yöntem olmasına rağmen, alışıldık kesme ile bölünmüş kurguya dayanan sahneleme anlayışından farklı bir estetik ve anlatım dili ortaya koyabilen plan-sekans yöntemi filmsel zaman ve uzam konusunda halen keşfedilmeye müsait bir alan olarak karşımızda durmaktadır.

Teknolojik gelişmeler konusunda ise önce dijitalleşme sayesinde kayıt süresi gibi önemli bariyerler aşılmış, bilgisayar üretimi görüntüler ile gerçek görüntülerin bir arada kullanımı yaygınlaşmıştır. Son olarak da ekipmanların küçülüp-hafiflemesi ve kamera taşıma araçlarının daha da çeşitlenmesi (drone'lar, gimbal'lar vb.) neticesinde, plan-sekans yöntemi yalnızca filmin yaratıcılarının hayal gücü ile sınırlanır hale gelmiştir. Ana akım ticari sinemada, sıklıkla yönetmenin "metteur en scene" olarak yeteneklerini sergilediği bir görsel şov olarak karşımıza çıkan plan-sekans, film dilini zenginleştirecek ve yeni anlam katmanları üretmekte kullanılabilecek önemli bir potansiyel barındırmaktadır. 
Bu kapsamda araştırmada incelenecek olan son dönem yapımlarından Sam Mendes'in 1917 (yapım yılı: 2019) filmi de tüm filmin tek bir plan (bir istisnai durum dışında) olarak tasarlandığı ve plan-sekans tekniğinin iyice geliştirilmiş örneklerinden sonuncusudur.

En basit tanımıyla filmi oluşturan en küçük birim olan plan, "sahnenin en küçük yapı taşıdır". Dolayısıyla sahneyi oluştururken planların birbirine eklenmesiyle "inşa" edilen bir dilden söz edebilmek mümkündür. (Brown, 2011:16). Bu inşa etme süreciyle ilgili olarak ilk kez gerçek anlamda Amerikalı yönetmen Griffith'e atfedilen "kurgu” (Bonitzer, 2006:20), aynı dönemlerde Sovyet biçimcileri Eisenstein ve Pudovkin tarafından da hem benzeri, hem de farklılaşan yönleriyle kullanılmıştır. Pudovkin'deki bu inşa, iki tuğlanın bir araya gelmesi gibi aşama aşama bütünü oluştururken, Eisenstein'da ise iki planın "çarpıştırılması" ve ortaya tek tek planların kendisinden farklı, yeni bir anlam ortaya çıkmasıdır (Büker ve Onaran, 1985: 14).

Ayrım olarak Türkçeleştirilebilen sekans, birbiriyle ilişkili sahnelerin bir araya gelmesiyle oluşmaktadır. Plan-sekans ise sahnenin tamamının tek bir planda çekilmesini ifade etmektedir. Bu haliyle bir plan-sekans sahnenin uzunluğuna göre çok basit-kısa ve sabit bir çekim olabileceği gibi, dakikalar uzunluğunda ve mekanların-oyuncuların değiştiği, hareketli kamerayla çekilmiş uzun bir sahneden de oluşabilir. Ancak burada yönetmenin kurgu yoluyla sahnenin temposu üzerindeki hakimiyeti kaybolduğu gibi, kurgu aşamasında sahneye anlam üretecek bir müdahalede bulunmak da imkansız hale gelmektedir. Bu yüzden işini "garantiye" almak isteyen yönetmenlere alternatif çekimler yapmaları tavsiye edilmektedir (Brown, 2011: 29-30).

Yönetmenin sahnenin kurgusu ve doğal olarak temposu üzerindeki hakimiyetini yitirmesi (ya da zayıflaması) sinemanın ilk yıllarındaki sabit bir kamera konumundan kaydedilen ve temponun oyuncu performansına bağlı olduğu yılları hatırlatmaktadır. Ancak plan-sekansın anlatım dili bakımından yönetmene sağladığı bazı avantajlar da bulunmaktadır. Theo Angelopoulos'a göre plan-sekans, filmde zaman ve mekan bütünlüğünü sağlamaktadır. Ayrıca kesme (cut) yaparak yapılan bir kurgu yerine kamerada bir kurgu yapılarak, bu yolla izleyiciye görüntüyü daha iyi inceleme fırsatı sunması bakımından da filme derinlik ve ayrıntı katmaktadır (akt: Savaş, 2019: 33).

Plan-sekans film içerisinde tek ya da birden fazla sahnede kullanılabileceği gibi Hitchcock'un Rope filminde yaptığı gibi tüm film baştan sona tek plandan oluşuyor gibi de uygulanabilmektedir (Monaco, 2001: 127). Burada yönetmenin sinema diline yaklaşımı ve işlenecek öykü kadar, filmlerin çekildiği dönemdeki teknik imkanlar ve filmin bütçesi de bu tercih üzerinde etkili olabilmektedir. Filmin çekim takvimi, oyuncu seçimi ve filmin çekileceği mekanlar da yine bu tercih ile ilişkili unsurlardır.

Plan-sekans tekniğinin filmin öyküsüyle uyumlu bir şekilde kullanıldığı ve başarılı bir şekilde "filmi tamamladığı" durumlarda, filmin dikkat çekmesinde etkili olduğu görülmektedir. Ayrıca uygulamanın eskisine göre teknik açıdan (nispeten) daha kolay hale gelmesi ile de, ana akım ticari sinema dışında da sinema sanatına katkı sunabilecek bir potansiyel barındırdığı söylenebilmektedir. Bu yönüyle plan-sekansın sinemadaki güncel kullanımı üzerine bir inceleme yapmak önemlidir. 


\section{Amaç, Yöntem, Örneklem ve Sınırlıklar}

Teknolojik gelişmeler toplumsal yaşamın ve kültürün her alanına etki ettiği kadar, toplumun ve çağın aynası durumundaki sinema sanatına da etki etmektedir. Sinemaya özgü anlatım biçimlerinin, yönetmenler tarafından sürekli bir keşif süreciyle ele alınması dönem dönem farklı biçimsel çabaların ortaya çıkmasına neden olabilmektedir. Plansekans yönteminin geçmişe göre daha sık karşımıza çıkması, bu teknolojik gelişmelerin sinemanın kullanımına sunduğu yeni araçlar-teknikler ve yönetmenlerin de bu yöndeki tercihleri sayesinde mümkün olabilmektedir. Dolayısıyla bu gelişmelerin sinemaya etkisi araştırmaya değer bir konu olarak karşımıza çıkmaktadır.

Bu çalışmanın amacı sinemada kullanılan teknolojik araç-gereç ve buna bağlı olarak gelişen tekniklerin, plan-sekans kullanımını nasıl etkilediğini ve bunun film biçemine yansımalarını incelemektir.

Çalışmada 1917 filmi üzerinden, sinemadaki teknolojik gelişmelerin bu tekniğin uygulanmasına sunduğu katkılar ortaya konacak ve bu doğrultuda plan-sekans'ın film biçemine etkileri betimleyici yöntem ile analiz edilecektir. Amaçlı örneklem olarak seçilen 1917, plan-sekans yöntemini kullanan filmler arasında bu teknik ile adından çokça söz ettiren en güncel örnektir, bu nedenle araştırmanın amacına uygun olarak tercih edilmiştir.

İncelenecek olan 1917 filmindeki plan-sekanslar gizli geçişler ve kesmeler ile birleştirilerek ardışık plan-sekanslar tek bir çekimden oluşuyor gibi bir etki elde edilmiştir. Fakat bu geçişler izleyici tarafından fark edilmesi zor, karmaşık bilgisayarlı görsel efektler ile gerçekleştirilmiştir ve film kare kare durdurularak izlendiğinde dahi tespit edilmesi son derece güçtür. Filmin yapım ekibi tarafından paylaşılan ayrıntılar ve nispeten kolay fark edilebilen geçişler dışında filmin senaryosundaki sahne ayrımları da yol gösterici olmaktadır. Bunlar dışındaki gizli geçişler ve kesmelerin tespiti ise mümkün olamamaktadır. Dolayısıyla film ekibinden doğrudan bilgi alamamak araştırmanın sınırılıklarından birisi olsa da, araştırmanın sonucuna önemli oranda etki etmemektedir.

\section{Plan-Sekans, Kurgu ve Sinemada Gerçeklik}

Jean Mitry plan ile sekans ifadesinin uzam ile zamana vurgu yapan iki kelime olduğunu belirterek plan-sekans kavramsallaştırmasına karşı çıkmaktadır. Fakat kendisinin de ifade ettiği gibi ortada dil ve çeviri farklılığından kaynaklanan bir sorun vardır. İngilizcedeki "take" ile "shot" kelimelerinin ikisine de "plan" denmesi bu soruna neden olmaktadır (Bonitzer, 2006: 19-20). Uygulamada plan kelimesi hem yapılacak çekimin süresini belirtmekte, hem de çekim ölçeklerine atıf yapmaktadır. Örneğin süre belirten "3 saniyelik bir plan" ile mekânsal boyut belirten "bel plan" gibi... Bu durum kafa karıştırıcı gibi görünse de aslında ikisi ile de ifade edilmek istenen şey bellidir ve setlerde sorun olduğu söylenememektedir. Gilles Deleuze (2014: 42), Mitry'nin plan hakkındaki düşüncelerini yorumladıktan sonra, plan kavramına "izdüşümsel, perspektif ya da zamansal anlamı tamamılla verilecek olursa, ... yeterli bir birliğe sahip 
olabilecektir" diyerek planın her iki unsuru da (zamansal ve mekânsal) barındıran bir ifade olduğunu ancak bazı özelliklerinin yerine göre ağır basabileceğini belirtmektedir.

Pudovkin uzun çekimi tiyatroya benzeterek yadsırken (Büker, 2010: 102) İtalyan yönetmen Pier Paolo Pasolini sinemada plan-sekans gerçeklik ilişkisi bakımından gerçek hayattan çarpıcı bir örnek vermektedir. ABD başkanlarından Kennedy'nin suikasta uğrama anını gösteren görüntüyü bir plan-sekans olarak tanımlayan Pasolini, kameranın bulunduğu konumu sübjektif olarak tanımlar ve "sübjektif çekim herhangi bir görsel-işitsel teknikte, gerçeğin en son noktasını temsil etmektedir. Çünkü gerçeği bir görüş açısından görmek ve işitmek mümkündür" der. Pasolini sübjektiflikten yola çıkarak sinemanın şimdiki zamanın röprodüksiyonunu" yaptığını ifade etmektedir. "Gerçek ile yaşamın röprodüksiyonu arasındaki yani yaşamla sinema arasındaki fark zamanın ritminde ve zamanın kendisindedir" (Pasolini, 1972).

Deleuze, sinemaya özgü hareket-imgenin, sinemanın ilk zamanlarındaki "ilkel" halinden kameranın hareketlenmesi ve montaj yoluyla sıyrılarak gerçekleştiğini ve sinemanın bu tür bir serbestlik istediğini ifade etmektedir. Burada kastedilen ilkellik, hareketin yalnızca sabit kamera önündeki cisimlerin ve insanların hareketini yansıtıyor olmasıdır. Daha sonraları devreye giren iki farklı yöntemle; hareketli kamera ve kurgu yoluyla bu hareketli-hareketsiz planların birleştirilmesi ise sinemada hareketimgenin oluşumunu mümkün kılmıştır (Deleuze, 2014: 41-42). Bu iki yöntem de çoğu zaman "görünmez tekniğe" dahildir (Brown, 2011: 29) ve özel bir amaç yoksa izleyicinin dikkatini çekmeden uygulanmaya çalışılmaktadır. Yani yavaşça ve yumuşak değişimlerle gerçekleşen kamera hareketleri ile birlikte, kurguda geçiş noktalarının hareket devamlılığını sağlayacak şekilde seçilmesi ve çekimlerini buna uygun bir planlama ile yapılması, çerçeve içindeki hareket sayesinde bu kesme noktalarının algılanmasının zorlaştırılması gibi yöntemler akla getirilmelidir.

Bonitzer (2006: 102), modern sinemadan bahsederken; izleyiciyi yönlendirme tutkusu içerisindeki yönetmenler tarafından planların kırıldığını ve aralarında yeni iliş̧iler kurarak, sıradan heyecanlara göre daha zor tanımlanabilen farklı tür bir duyum yaratıldığını ifade etmiştir. Griffith ile başlayıp Eisenstein ve Hitchcock gibi yönetmenler tarafından çok etkili bir şekilde uygulanan bu "izleyiciyi yönetme" yaklaşımının karşıtı ise Yeni Dalga'da (Nouvelle Vague) ortaya çıkmıştır. "Cahiers du Cinema" geleneğinin önde gelen isimlerinden Andre Bazin, özellikle Eisenstein ile özdeşleştirilen Rus Okulu'nun kurgu yaklaşımını, "seyircinin kendisine kurgu yoluyla dikte edilenden başka bir anlam bulması engelleniyor" diyerek eleştirmiştir (Perkins: 1974:33'den akt: Abisel ve Eryılmaz, 2014: 42). Kurgu aracılığıyla gerçeğin yönlendirilmesine karşı bir tutum benimseyen Bazin'in, gerçekçiliğini övdüğü anlatım biçimi ise Renoir'ın yaptığı gibi uzun çekimler, kaydırma (tracking/traveling shot) ve kompozisyonda derinliği (alan derinliği) kullanmadır (Abisel ve Eryılmaz, 2014: 42). Hem Yeni Dalga'da hem de Yeni Gerçekçilik'te hayat bulan bu anlatım biçimi Theo Angeloupulos, Bela Balazs, Antonioni gibi yönetmenler tarafından da benimsendiği gibi, 2000'lerden sonra çekilen birçok plan-sekans ya da tek çekim yöntemiyle üretilmiş filmler ile de benzeşen bir yapı arz etmektedir.

Sinemada karmaşık bir konu olan biçem temelde bir üslup ve yaklaşım tarzıdır ve 
farklı zaman periyodlarına, türlere ve aynı zaman da yönetmenlere göre değişiklik göstermektedir. Teknolojik gelişmeler de bu yıllar ve dönemler boyunca film diline önemli oranda etki etmiştir. Bir filmin öyküsü kadar öykünün ne şekilde anlatıldığı da önem arz etmektedir. Bu öykü ve anlatım biçimi ikilisi, sinema anlatısının temelini oluşturmaktadır (Topçu, 2008: 139). Çağdaş Amerikan Sineması'ndaki baskın biçem ise David Bordwell'in "yoğunlaştırılmış devamlılık kurgusu" dediği ve geleneksel devamlılığa göre vurguların daha sık ve yoğun yapıldığı yönteme dayanmaktadır. Bordwell daha hızı yapılan kesmeler (ortalama çekim süresinin kısalması), yakın çekimlerin yoğunlaşması ve hareketli kameranın da sık kullanılmasının, ana akım Amerikan Sineması'nda yaygın biçem olduğunu ifade etmektedir (Bordwell, 2008:144182).

Eisenstein'a göre; sinemayı sanat yapan gerçekliğin birebir temsilinin sunulması değil, aksine gerçeklikle bağını koparmasıdır. Bunu yapmanın yolu da kurgudur. O’na göre film parçası (kastedilen plandır) gerçekliğin yeniden üretimi iken kurgu gerçeklikten kopmanın koşuludur. Bazin ise; kurguyu tamamen yadsımamakla birlikte planlar arasındaki ilişkiyi yadsımakta ve uzun çekimin de anlamlı olabileceğini ifade etmektedir. Eisenstein kurgu sayesinde izleyicinin filme katılacağını söylerken Bazin, uzun çekim sayesinde bunun gerçekleştiğini savunur. Bazin'e göre biçimci yaklaşımda izleyici, yönetmenin görülmesini istediğini görürken, gerçekçi yaklaşımda ise görmesi gerekeni görür (Büker, 1989: 7, 22).

Arnheim sinemanın sanat oluşunu, onun gerçeğin kısmi bir yanılsaması olmasıyla mümkün olduğunu ifade etmektedir. Üç boyutlu gerçek dünyanın filmde iki boyuta inmesi, derinliğin azalması, çerçevenin sınırları olması ve kurgu yoluyla filmsel zaman-mekanın kesintiye uğraması gibi nitelikleri nedeniyle sinema dış dünyadaki gerçeği perdeye aktarırken, bu sınırlılıklardan yararlanılarak film bir sanat ürünü haline getirilebilmektedir (Büker ve Onaran 1985: 14-15). Arnheim, kamera ile insan gözünün gerçeklikten yarattığı görüntünün arasındaki önemli farklılıkları vurgulayarak, kameranın gerçekliği sanatsal olarak biçimlendirmek için kullanılabileceğini öne sürmüştür. "Sinema tekniğinin dezavantajları olarak adlandırılabilecek -ve mühendislerin üstesinden gelmek için ellerinden geleni yaptıkları- şeyler gerçekte yaratıcı sanatçının araçlarıdır" (Arnheim, 2002: 110). Bu görüşten yola çıkılarak bugün sinemada kullanım alanı bulan yeni her tür aracın ve tekniğin bu sanatsal üretimin ve sanatçının araçları olduğu söylenebilmektedir. Buna, sınırları çizilemeyen ve her geçen gün gelişen bilgisayar üretimi görüntüler de dahildir.

Sinemanın gerçeklik ile ilişkisine dair iki kutupta toplanan ve temelde yapay perspektif ile doğal perspektif farkı üzerine odaklanan görüşleri Bonitzer (2006: 115) birer örnek üzerinden şu şekilde özetlemektedir;

İlk görüş:

"Sinematofgrafik aygıt bütünüyle ideolojik bir aygıttır. Doğrudan doğruya Quattrocento'nun (14. yy İtalyan sanatsal olaylarının toplu adı) bilimsel perspektifinin mirasçısı olan, bu perspektif model alınarak inşa edilmiş bir perspektif kodu üretir. Şerh: Kameranın gerçek'le herhangi bir nesnel ilişki kurması imkansızdır." 
Karşı görüş:

"Sinematofgrafik aygıt ideolojik olarak tarafsız bir aygıtır. Doğal göz algısını mekanik olarak yeniden üretir. Şerh: Kamera hedeflenen gerçek'i nesnel olarak aktarır."

Bu iki görüşü karşılaştıran Bonitzer'e göre kameranın Quattrocento'nun perspektif mirasını almış olması onun nesnelliğini engellemezken aynı zamanda o dönemin perspektifini de bilimsel olarak nitelemek, temsile kısmen de olsa nesnel bir statü vermektedir bu yönüyle kendi içerisinde bir çelişki barındırmaktadır. Öte yandan aygıtın göz algısını taklit ediyor olması da onu tamamen nesnel yapmaz zira göz algısı bizatihi yanılsamaya açıktır. Bunlara kendi yorumunu ekleyen Bonitzer (2006: 116119); "aygıtın gerçek karşısındaki nesnelliği sorusuna (minyatür çekimlerini ve yapay dekorları da örnek göstererek), gerçek'in hileli niteliği ile cevap vermek mümkündür" demiştir.

Plan-sekans ve tek çekim filmler konusunda öne çıkan filmlerden Russian Ark (2002 Alexander Sokurov) ve Victoria (2015 - Sebastian Schipper) gibi filmler gerçek anlamda baştan sona tek bir plan olarak çekilmesiyle diğer plan-sekans kullanılan filmlerden ayrılmaktadır. Rope, Birdman (2014 - Alejandro Gonzales Inarritu) ve 1917 gibi filmler ise plan-sekans'lar arasında "gizli" kesmeler yaparak "tek çekim" izlenimi yaratılmaya çalışılan filmlerdir. Bunun dışındaki bir diğer kategori ise filmin belirli anlarında ayrık bir biçimde kullanılan (bir kez ya da daha fazla) plan-sekans'ların yer aldığı filmlerdir ki, burada sayılamayacak kadar çok filmde bu yönteme rastlayabilmekteyiz. Gerçek anlamda tek çekim bir film yapmak ise gerçek zaman ile filmsel zaman arasında tam bir paralellik kurmaktadır. Yine Pasolini'nin bu konudaki görüşlerine dönecek olursak;

Bir çekimin uzunluğu ve sıralanış ritmi, filmin değerini değiştirip onu bir ekole, döneme ya da ideolojiye dahil etmektedir. Eğer sinemanın plan-sekansında illüzyon sadece kurgunun yardımıyla elde edilebilir diye düşünüyorsak, o zaman plan-sekansın değeri daha idealize bir dünyanın plan-sekansı olmaktadır. Aslında hakiki plan-sekans, gerçekte görünmüş aksiyonu, gerçek zamanın uzunluğuyla göstermektedir. Simule edilen plansekans ise, -ki ona en fazla Yeni Gerçekçi filmlerde rastlıyoruz- gerçekteki aksiyonun taklidini yapmaktadır. Gerçeğe ait aksiyonun, çeşitli yönlerine ait röprodüksiyonudur bu. Ardından da tüm bunları zamanın süreğenliğinde tekrar birleştirmektedir. Bu arada da kendisinin doğalmış gibi üstlendiği rolü gizlemektedir (Pasolini, 1972).

Bu ifadeden de anlaşıldığı üzere; plan-sekans kullanım biçimi yönetmenin sinema dili, estetik, gerçekçilik ve filmsel zaman-uzam gibi konulardaki tercihleri ile şekillenmektedir. Ancak bu çalışma kapsamında plan-sekansın, teknik-teknolojik gelişmeler ile nasıl şekillendiği ve sinema diline nasıl etki ettiği tartışılmak istenmektedir. Unutulmamalıdır ki yönetmenin vizyonu öyle ya da böyle elindeki olanaklarla sınırlanmaktadır. Teknoloji geliştikçe yeni teknikler de sinemada yeni anlatım biçimlerine imkan sağlayabilecektir. Tıpkı geçmişte sesin sinemaya girmesi, filmlerin renklenmesi gibi gelişmeler nasıl sinemanın anlatım biçimine yön verdiyse (Arnheim, 2002: 132-134) drone'lar, gimbal'lar, aksiyon kameraları, CGI vb. gelişmeler de sinematografiye ve doğal olarak film biçimine katkıda bulunmaya devam edebilecektir.

Araştırma kapsamında baştan sona tek çekim olan ya da tek-çekim gibi görünen birçok kısa film, deneysel ve amatör filmle karşılaşılmıştır. Burada bahsi geçen örnek filmler ise profesyonel uzun metraj kategorisine giren ve uluslararası dağıtıma/gösterime çıkmış, dolayısıyla konunun ilgilisi tarafından da erişimi mümkün olan filmler arasından 
seçilmiştir. Bölüm 2.1 ve 2.2. de kronolojik bir tespit yerine, konunun anlaşılmasında yarar sağlayacak şekilde eski ve yeni örneklere yer verilmiştir. Bu örnekler arasında 2002 yılında çekilen Russian Ark filmi video kamera ile çekilmiş profesyonel bir yapım olması açısından diğer örneklerden ayrılmakta ve teknik gelişmelerin sinemaya etkisi açısından üzerinde durulması gereken bir örnek teşkil etmektedir. Sebastian Schipper'in Victoria'sı da bu tür yapımların en güncel örneklerinden biri olması sebebiyle kısaca değerlendirilmiştir. Tek çekim gibi görünen filmlerden örnekler; ana akım sinemada ilk örnek olan ve bu tür çabalara kapıyı aralayan Rope ve teknik gelişmeler sayesinde Rope'dan 66 yıl sonra gelinen noktayı göstermesi açısından Birdman olmuştur.

\subsection{Tek Plan Olarak Cekilen Filmler}

Alexander Sokurov'un yönettiği 2002 yapımı Russian Ark filmi baştan sona kesintisiz olarak, hareketli bir tek plan (Steadicam kullanılarak) olarak çekilmiştir. Filmin konusu Rusya'nın 18. yy başından itibaren günümüze uzanan tarihsel sürecini ve Avrupa kültürü ile ilişkisini konu almaktadır ve müzede sergilenen eserler ve farklı tarihsel dönemleri canlandıran figüranlar arasında süzülen bir kamera ile izleyiciyi bir nevi zaman yolculuğuna çıkarmaktadır. 90 dakikalık film, St. Petersburg'daki Hermitage Müzesi'nde 2000'in üzerindeki oyuncu, figüran ve ekip üyesi ile çekilmiştir (Seville Pictures).

Filmin ilgi uyandıran tek-plan uygulaması dışında yönetmenin vizyonu ve filmin anlatısı da birçok övgüye ve farklı alanlardan akademik çalışmaya da konu olmuştur. Fakat Rus-Alman ortak yapımı filmin Alman görüntü yönetmenine (aynı zamanda Steadicam operatörü) 2002 Avrupa Film Ödülleri'nde ödül verileceğini duyan Yönetmen, organizasyona bir mektup yazarak filmini çekmiştir. Filmin sadece görüntü yönetmenine ödül verilecek olmasını diğer ekip üyelerinin emeğine haksızlık olduğunu belirten yönetmen, filmin fikir babasının, yönetmeninin ve senaryo yazarlarından birisinin kendisi olduğunu hatırlatarak "film bir bütün olarak ele alınmalıdır" demiştir (Sokurov, 2002). Bu anekdota burada yer vermemizin sebebi hem endüstride hem de sanat çevrelerinde bu tür teknik "başarıların" hala içeriğin önüne geçebildiğini ve tekplan filmlerin bir şov olarak görülebildiğine örnek oluşturmasıdır. (Yönetmenin tavrı ya da bazı kategorilerde ödül alan filmlerin başka kategorilerde ödül almıyor oluşu başka bir tartışma ve çalışmanın konusudur).

Film küçük sensörlü bir HD kamera ile çekilmiş fakat görüntüler 46 dakikalık bant sınırı sebebiyle sıkıştırmasız (uncompressed) olarak kameraman ile birlikte hareket eden bir asistanın sırtına yerleştirilmiş, 100 dakika kapasiteli-sabit disk tabanlı kayıt cihazına kaydedilmiştir. Filmin görüntülerinin kurgu sırasında gerektiğinde yeniden kadrajlandığı (re-framing), bazı yerlerde de hızlandırma ya da yavaşlatmanın kullanıldığı, bunun dışında renklendirme, obje silme vb. müdahalelerin de yapıldığı bilinmektedir (Wilfert, ty). Bu açılardan değerlendirildiğinde tek-plan olarak çekilmesinden kaynaklanan bazı zorluklar ve sorunların dijital yöntemlerle aşıımaya çalışıldığı söylenebilmektedir. Teknolojinin bu tür bir filmi "çekilebilir" hale getirmesi için 2000’li yılların beklenmesi gerekmiştir (Seville Pictures). 
Sebastian Schipper'in yönettiği Victoria (2015) filmi baştan sona gerçek anlamda tek bir plan olarak hiç kesinti yapmadan çekilmiştir. Berlin'de gece sabaha karşı sokakta bir grup "göçmen" Berlinli ile karşılaşan ve kendisi de göçmen olan (İspanyol) Victoria, yeni arkadaşlarıyla vakit geçirirken kendisini bir anda kanlı biten bir banka soygunu içinde bulur ve aynı zaman zarfında gelişen ve çok kısa süren de bir aşk yaşar. Birkaç saat içerisinde gerçekleşen bu olayları gerçek zamanlı bir biçimde anlatan film, plan-sekans tekniği ile çekilmeye uygun bir öykü yapısına sahiptir. Filmin gerçekleştirilmesi kompakt bir dijital kamera (küçük bir lens ile) ve tek bir kameramanın tüm film boyunca olayları el kamerası (handheld) yöntemiyle kaydetmesiyle mümkün olabilmiştir. Kameranın batarya ve kayıt kapasitesinin yeterli olması işin bir bölümünü kolaylaştırsa da, geriye kalan ses, ışık ve daha da önemlisi aktör performansları için defalarca provalar, tekrarlar ve denemeler yapılmıştır. Film kısmen büyük oranda gerçek mekanlarda çekilmiş olmasıyla geçmişteki bazı örneklere göre daha cesur bir girişime imza atmıştır. Bu noktada filmin yönetmeninin film ile ilgili yaptığı söyleşilerden anlaşıldığı üzere; tek bir plan olarak bütün filmi çekme düşüncesi yönetmeni çok heyecanlandırmış ve aynı zamanda da endişelendirmiştir. Zira konvansiyonel yöntem diyebileceğimiz kesmeli kurgu anlayışıyla yapmaya göre büyük riskler barındıran bu yöntem filmin yapımcılarını da endişelendirmiş ve film çekilirken ilk önce (alternatif biçimde) kesmelerle kurgulanmak üzere birkaç versiyon çekilmiştir. 10'ar dakikalık parçalara halinde ve gerektiğinde sıçramalı kurguyla (jump cut) kurgulanabilecek şekilde çekildikten sonra, en son üç tekrar tamamen kesintisiz plan-sekans olarak "denenmiş" ve başarılı olunduğunda bu versiyonun kullanılmasına karar verilmiştir (Schipper, 2016). Bu yaklaşımdan anlaşılan; bu tür girişimler aynı zamanda yönetmenler tarafından bir gövde gösterisi, güncel ifadeyle adeta bir "meydan okuma (challenge)" olarak da görülebilmektedir. Zira film ile ilgili medyada çıkan değerlendirmeler hep filmin tek-plan olması üzerinde yoğunlaşmış hatta Hitchcock'un Rope'u ve Birdman filmleriyle kıyaslanmıştır. Yine yönetmenin kendisi bu tür bir film çekmeyi tekrar düşünmediğini ve başkasına da tavsiye etmediğini ifade etmiştir (Barnes, 2016).

Schipper, sıçramalı kurgu ile filmi yapmayı "garantiledikten" sonra plan-sekans versiyonu çekmiştir. Ancak yine de film nihai hali üzerinden değerlendirildiğinde yönetmenin yorumuna göre; yaşanan atmosferi, duygu geçişlerini ve öyküdeki gerilimitansiyonu en samimi ve gerçekçi şekilde bu plan-sekans versiyonu ortaya koymuştur. Kendisi de oyuncu kökenli olan Schipper, oyuncuların 12 sayfadan oluşan senaryoyu bütünüyle okumadıklarını, kendisinin de oyuncuları ve filmin tüm mikro-ayrıntılarını kontrol edemeyeceğine inandığını ifade ederek, oyuncuları yalnızca yönlendirerek onların hislerine güvendiğini söylemiştir (Schipper, 2006).

\subsection{Tek Çekim Gibi Görünen Filmler}

Alfred Hitchcock'un yönettiği Rope (1948), tamamı plan-sekanslardan oluşan 10'ar dakikalık bölümlerin arasında "gizli" kesmeler yapılarak kesintisiz ve tamamen tek bir çekimden oluşuyormuş gibi görünen bir filmdir bu yöntemin sinemadaki ilk örneğidir. Rope filminde her çekim 10 dakikadan oluşmaktadır ve bu süre aslında kameraya takılabilen filmin maksimum süresidir. Bu sürenin bitiminde ise kameranın önünde 
olayı karartacak şekilde bir çekim yapılarak, film bobini değiştirildiğinde aynı yerden başlanmış ve böylece iki kesmenin arasındaki fark en aza indirilerek "gizli" bir kesme yapılabilmiş ve bu "hile" izleyicinin gözünden kaçırılabilmiştir (Truffaut, 1987: 175). Tabi filmin çekildiği 1948 yılında sinemada ilk kez denenen bu uygulamayı o zamanın standartları içerisinde değerlendirmek gerekmektedir. Bugün Rope filmi deneyimli bir sinema izleyicisi tarafından izlendiğinde kesmeler kolayca göze çarpmakta (kameranın zorlama bir şekilde karanlık bir yüzeye yakınlaşması vb.) ve tahmin edilmektedir.

Tiyatro oyunundan uyarlanan bu filmde olaylar gerçek zamanda kesintisiz olarak geçtiği için Hitchcock da bunu sinemada yapmayı denediğini ifade etmiştir. Fakat montajın önemi konusundaki kendi teorilerine zıt bir iş olarak değerlendirdiği bu filmi "saçma" olarak niteleyen Hitchcock, oyuncuların ve kameranın hareketlerini planlarken sahnenin heyecan durumuna göre görüntünün boyutunu (ölçekleri) çeşitlendirdiğini belirtmektedir (Truffaut, 1987: 175). Buradan anlaşılacağı üzere montaj ile oluşturulan film dilinden farklı bir dil ortaya çıktığı ortadadır. Yönetmenin sahne üzerindeki kontrolü apaçık biçimde azalmaktadır fakat yine de hareketli kamera ve iyi planlanmış bir mizansenle tiyatro ile kıyaslanmayacak farklı bir film dili de oluşturulabilmektedir.

Hitchcock Rope filmini bir deneyim olarak görürken D.W. Griffith'e atıf yaparak, "filmler kurgulanmalıdır" demiştir (Truffaut, 1987: 179). Öte yandan yapımcılığını da kendisinin üstlendiği filmin çok ilgi gördüğü ve ticari olarak da önemli bir başarı elde ettiği bilinmektedir. Hitchcock, François Truffaut ile yaptığı söyleşide Rope için "bu filmi bir hüner gösterisi olarak yapmışım, bu filmi betimleyebilmenin tek yolu bu" demiştir (Truffaut, 1987: 174).

Bu kategoride modern bir örnek ise Alejandro Gonzales Inarritu'nun Birdman filmidir. Mekan olarak bir tiyatro binasında geçen ve yaklaşan bir tiyatro oyununa hazırlanan karakterler etrafında gelişen film büyük oranda tek bir sürekli çekim gibi görünmektedir. Kameranın gökyüzüne döndüğü ve geceden gündüze geçiş gibi zamanda atlamaya neden olan çekimler olsa da sürekli hareket halindeki kameranın karekterleri durmaksızın takip ettiği çekimler arasında gizli geçişler ile tek çekim izlenimi sürdürülmüştür. Karanlık çerçevelerle, kamerayı bloke eden objelerle, kapılarkolonlarla gizlenen geçişlerde yoğun görsel efekt kullanımıyla kesmeler gizlenmiştir. Dikkati çeken bir başka kesme yöntemi de kameranın çok hızlı bir şekilde çevrindiği (whip pan) ve oluşan flu karelerin diğer çekim ile birleştirmek için kullanıldığı tekniktir. $\mathrm{Bu}$ yönteme diğer geçiş türlerine göre daha sık rastlandığı görülmektedir. Birdman filmi güncel teknikler ve imkanların verdiği cesaretle üretilmiş güncel bir örnektir fakat gerek öykünün kısıtlı bir mekanda geçiyor oluşu, gerekse de kullanılan geçişlerin bazen "zorlama" bir etki yarattığı ve kamera hareketini amaçsız gibi gösterdiği de gözlemlenmektedir. Ancak yine de hem tekniğin hem de anlatım biçiminin epey ilgi çekmiştir. Bu filmin ekibinde yer alan görüntü yönetmeni Emmanuel Lubezki yine Inarritu ile beraber Revenant (2015) filminde de uzun çekimler ve gizli geçişlerle film yapma eğilimleri göstermiş, kendisi gibi Latin Amerikalı olan yönetmen Alfonso Cuaron ile Gravity (2013), Children of Men (2006) gibi filmlerde de benzeri yöntemleri kullanmıştır. Dolayısıyla Birdman filmi bu ikilinin benimsediği üslubun zirve noktası olarak anılabilmektedir (Variety, 2014 ve Renee, 2015). 


\section{Plan-Sekans Kullanımını Kolaylaștıran Teknik Gelișmeler}

Martin Scorsese'nin Irishman (2019) filmini çekebilmek için projesini yıllarca erteleyerek, gerekli mali kaynağı bulmak için çok uğraştığını belirtmesi ve filmdeki aktörlerin gerçekçi bir biçimde "gençleştirilebilmesi" için gerekli düzeydeki bilgisayar teknolojisinin ancak ulaşılabilir olması (Pulver, 2019), teknik ve mali konular ile film biçimi arasındaki ilişkiye örnek gösterilebilmektedir. Nitekim film senaryosu yazılırken dahi, senaristlere tasarlanan filmin "çekilebilir" olması salık verilmektedir (Akyürek, 2004). $\mathrm{Bu}$ örnekten anlaşıldığı üzere bazı filmlerin ve sahnelerin gerçekleştirilebilmesinde teknik olanakların rolü yadsınamamaktadır.

Tek çekim olarak gerçekleştirilen Russian Ark filminin çekildiği dönemde (2002), bu şekilde gerçekleştirilebilmesine olanak tanıyan video kamera teknolojisindeki gelişmelerdir. Fakat filmde kullanılan Sony CineAlta HDV-F900 kamera, HD (Yüksek Tanımlı) çekim yapabilen ama küçük sensörlü ( $\square$ inç) bir kamera olduğu için (Russkiy kovcheg, imdb.com) günümüzdeki $35 \mathrm{~mm}$ eşdeğeri sensör boyutuna sahip dijital kameraların ürettiği görüntü kalitesine ve daha da önemlisi sığ alan derinliğine ulaşamamaktadır. Bu sebeple bu tip küçük sensörlü kameraların ana kamera olarak kullanıldığı film sayısı son derece azdır ve çok tercih edildiği söylenememektedir (shotonwhat.com). Tabi bu kameralara has bir görüntü estetiğinin özellikle tercih edildiği filmler de mevcuttur; derin/geniş alan derinliği (deep focus/deep depth of field) ve videoya özgü renk uzayının bazı filmlerde öykü anlatımının bir unsuru olarak kullanılması söz konusudur. Örneğin Wachowski Kardeşler'in 2008 yapımı Speed Racer filminde yönetmenlerin yaratmak istediği evrene iyi hizmet edeceğine karar verilerek yine küçük sensörlü bir video kamera kullanılmıştır (Frazer, 2008). Dolayısıyla video kamera ile $35 \mathrm{~mm}$ filmin kalitesine yaklaşabilen/geçebilen bir kalitede sinema filmi çekebilmek için 2010'lu yıllara gelinmesi gerekmiştir.

Video ile 35mm negatif film arasındaki farklılıklara değinen Bonitzer (2006: 33-36), videoyu film estetiği bakımından sert bir biçimde eleştirmektedir (kitabın yazıldığı 1982-85 dönemindeki video teknolojisinin şimdiye kıyasla epeyce düşük kaliteli olduğu ve birçok dezavantaja sahip olduğu akılda tutulmalıdır). Ancak içinde bulunduğumuz 2020 yılı itibariyle çekilen sinema filmlerinin çok büyük bir bölümü artık tamamen dijital olarak çekilmektedir (Follows, 2019). Dijital sinema kameraları olarak adlandırılan bu kameralar sıradan video kameralardan da farklı bir sınıfta yer almakta olup, hala bazı sorunları olsa da, kalite konusunda film ile kıyaslanabilir bir noktaya ulaşmıştır. Filmin organik dokusu ile videonun dijital yapaylığı konusundaki estetik/ felsefi tartışmalar ise süreceğe benzese de, sinemada dijital kameralardan geriye dönüş mümkün görünmemektedir. Dijital sinema kameralarının gelişimini sürdürüyor olmasına karşın negatif film üretimi sürekli azalmakta ve film işlenen laboratuvarlarda hızla kapanmaktadır (Kendricken, 2013). Öte yandan çok büyük bütçeli Hollywood yapımlarında bazen daha da eskiye dönüşle, $65 \mathrm{~mm}$ negatif filmle çekilen bazı istisnalar dışında (antikalaşmış kameralar-lensler, negatif film stoğu ve laboratuvar imkanları vb. nedenlerle fazladan büyük maliyetler getirmektedir), film artık nostaljik bir anlam da ifade etmeye başlamıştır. Günümüz dijital kameralarıyla çekilen görüntülerin bazı durumlarda dijital "gren" (noise) eklenerek eskitilmesi ve "filmik ya da film görünümü" 
yaratılmak istenmesi ise negatif filmin estetik hafızamızdaki yerini halen koruduğunu göstermektedir.

Kameraların kendisi dışında hareketli plan-sekans çekimleri için kameraya hareket vermeye yarayan film ekipmanları konusunda da sürekli bir gelişim yaşanmaktadır. Kamera taşıyabilen drone'ların gelişip yaygınlaşması ile düşük bütçeli yapımlardan büyük prodüksiyonlara kadar farklı ölçekteki film setlerine giren drone’lar ile alışılmadık kamera açıları, canlılara yakın çekimler, kapalı mekanlarda yapılan drone çekimleri, küçük ve dar alanlarda yapılan çekimler yanında, havadan-karaya ve karadanhavaya devam eden uzun çekimler gibi çekim yöntemleri mümkün hale gelmiştir. Drone'lar kadar bunlara monte edilen kameraların sarsıntıdan etkilenmesini azaltan ve kameranın stabil bir şekilde istenen yönde çekim yapabilmesini sağlayan gimbal'lar da bu imkanları zenginleştirmiştir. Gimbal'lar (DJI, Mövi, Zhiyun vb.) daha önceleri icat edilen Steadicam gibi kesintisiz hareketli çekim yapılabilmesini kolaylaştıran aletleri daha da yetenekli hale getirmiş ve iki sistemin bir arada kullanıldığı mekanik-elektronik melez cihazlar gelişmiştir (Arri Trinity gibi...). Gimbal'lar neredeyse her türlü hareketli araç, yüzey ve canlıya da monte edilebilmektedir. Bir kameranın tripod üstünde ve de ray üstündeki hareketlerinin defalarca ve kare hassasiyetinde (frame accurate) tekrar edilebilmesini sağlayan Motion Control (Milo, Bolt vb.) sistemleri de hem bazı görsel efektlerin gerçekleştirilebilmesi, hem de uzun çekimlerin hatasız tekrar edilebilmesi gibi açılardan film ekiplerinin işini kolaylaştırmıştır. Kameralar gitgide küçülmüş ve hafiflemiş, uzun çekimlerin kameraman tarafından fiziksel açıdan daha kolay yapılabilmesine olanak tanımıştır. Yine kameramanın yükünü hafifleten farklı destek sistemleri de (EasyRig vb.) aynı doğrultuda uzun çekimlerde kolaylık sağlamaktadır. Kayıt medyalarının kapasitelerinin çok artması ve birden fazla kayıt yuvasına sahip dijital kameraların bunları "kesintisiz" kullanabilmesi gibi yöntemlerle (relay recording) teorik olarak kayıt süreleri de neredeyse sonsuz hale gelebilmiştir. Batarya sistemleri de teknolojik gelişmelerden payını almış ve düşük güç tüketen ekipmanlarla birlikte uzun çekimlere daha uzun süre eşlik edebilir hale gelmiştir.

Kameralar ve destek ekipmanları açısından bu gelişmeler yaşanırken aşağı yukarı her 18 ayda bir yaklaşık olarak ikiye katlanan bilgisayar işlem kapasitesindeki artışlarla (Moore Yasası) ve yazılım teknolojisinin de ayak uydurmasıyla, bilgisayar üretimi görüntülerin (CGI) sinemada kullanımı her geçen gün daha da mümkün hale gelmektedir. Zira üretilen görüntülerin daha gerçekçi görünebilmesi bilgisayar donanımı ve yazııımının gelişmesi ile de paralellik göstermektedir. Dolayısıyla daha önceleri çok daha yüksek maliyetler ve zaman gerektiren bazı görsel efekt uygulamaları da mesafe kat etmiştir. Bu tekniklerin gelişmesi Hitchcock'un Rope filminde tamamen göz yanılsamasına dayanan gizli kesmelerini, bilgisayarlar ile üretilen "hileli” geçişlerle yapılabilir hale getirmiştir.

Yapım aşamasında kullanılan teknikler, ekipmanlar vb. dışında günümüzde bir filmin nihai haline etki edebilecek en önemli aşamalardan birisi de post-prodüksiyon aşamasıdır. Özellikle plan-sekansların çekilmesi kadar, kurguda bunların çeşitli yöntemlerle birleştirilerek kurgu yapılmamış ve film kesintisiz bir biçimde çekilmiş gibi bir izlenim oluşturmak için Rope'dan beri bilinmekte olan yöntemler dışında teknoloji sayesinde bilgisayarlarla maskeleme, rotoskopi, kompozitleme/birleştirme 
(compositing) ve CGI tekniklerinden yararlanılmaktadır.

Maskeleme bir dijital görüntü karesinin bir bölümünün diğer bölümlerden izole edilebilmesi anlamına gelmektedir. Başka bir deyişle ilgili bölümün kesilip ayrılabilmesi, farklı bir işleme tabi tutulabilmesidir. Maskelemede seçili alan ya da bu alanın dışı ayrı ayrı işlenebileceği gibi, birden fazla maskenin bir arada kullanılabilmesi ve birbirine eklenip çıkarılması da mümkündür. Video gibi hareketli görüntüler söz konusu olduğunda ise ardışık kareler arasında bu maskelerin biçim ve yer değiştirmesi ihtiyacı duyulmaktadır. Zira hareketli objeler ancak bu şekilde maskelenebilmektedir. Bu hareketli maskeleme işlemine rotoskopi adı verilmektedir. Rotoskopide, maskelemenin operatör tarafından her bir karede ayrı ayrı düzenlenmesi gerekmektedir. Dolayısıyla çok yorucu ve uzun süren bir işlem söz konusudur. Ancak yazılım ve donanım konusundaki gelişmeler sayesinde bu işlemlerde operatör müdahalesini azaltan ve zaman kazandıran izleme (tracking) teknikleri de mevcuttur ve etkili bir şekilde rotoskopi yapılabilmesi için bu teknikler bir arada kullanılmaktadır. Kompozitleme ise farklı kaynaklara ait görüntü katmanlarının diğer görüntü katmanları ile birleştirilmesi anlamına gelmektedir (Van Hurkman, 2014: 368-375).

\section{1917 Filminin İncelenmesi}

\subsection{Filmin Künyesi}

Yönetmen: Sam Mendes

Senaryo: Sam Mendes, Krysty Wilson-Cairns

Yapımcılar: Sam Mendes, Pippa Harris, Jayne-Ann Tenggren, Callum McDougall, Brian Oliver

Yönetici Yapımcılar: Jeb Brody, Oleg Petrov, Ignacio Salazar-Simpson, Ricardo Marco Bludé

Oyuncular: George MacKay, Dean-Charles Chapman, Mark Strong, Andrew Scott, Richard Madden, Claire Duburcq, with Colin Firth and Benedict Cumberbatch

Görüntü Yönetmeni: Roger Deakins

Kurgu: Lee Smith

Muzik: Thomas Newman

Yapım Şirketi: DreamWorks Pictures, Reliance Entertainment, New Republic Pictures, Mogambo, Neal Street Productions, Amblin Partners.

\subsection{Filmin Kısa Öyküsü}

1. Dünya Savaşı'nda Fransa'nın kuzeyinde, Almanlara karşı savaşan İngiliz ordusunda görevli Onbaşılar Blake (Dean Charles Chapman) ve Schofield (George MacKay) telefon hatları kesik olduğu için düşman hattı gerisindeki birliklerine haber ulaştırmakla görevlendirilirler. Aksi halde yanlış istihbarat sonucunda atağa hazırlanan İngiliz birliği tuzağa düşecektir. General tarafından Blake'in seçilmesinin özel nedeni ise Blake'in abisinin de diğer birlikte görev yapan bir Subay (Teğmen) olmasıdır. Abisinin hayatından da endişe eden Blake, yanına bir kişi seçmek durumundadır ve bu da arkadaşı onbaşı 
Schofield olur. İkili görevlerini yerine getirmek üzere kendi siperlerinden ayrılarak iki hat arasında kalan bölgeyi geçip, diğer birliğe haberi zamanında ulaştırmak üzere yola çıkarlar. Ancak yolda henüz terk edilmiş bir çiftlikte düşen bir Alman uçağının pilotuna yardım etmek isterlerken Blake, yaralı Alman pilot tarafından öldürülür. Böylelikle 1600 kişilik İngiliz birliğinin ve arkadaşı Blake'in abisinin hayatını kurtarma görevi tek başına Schofield'a kalır. Schofield yoluna devam ederken bir Alman keskin nişancı ile girdiği çatışmada miğferine gelen kurşunla ölümden döner ve bir anlığına bayılır. Gece yarısı uyandığında ise içinde bulunduğu kasabanın Almanlar tarafından tamamen ateşe verildiğini görür ve kendisini adeta bir cehennemde bulur. Rüya mı gerçek mi? olduğunu anlamaya çalışan Schofield O'nu fark eden Almanlar tarafından kovalanır ve yakındaki nehre atlayarak son anda ölümden kurtulur. Nehirde bir süre sürüklendikten sonra hava aydınlanır ve sürüklendiği yerde haberi ulaştıracağı İngiliz birliğini bulur. Bitkin haldeki Schofield son bir gayretle karargaha ulaşır ve son anda harekete geçmek üzere olan İngiliz birliğinin durmasını sağlayarak görevini başarıyla yerine getirir.

\subsection{Filmindeki Plan-Sekans Uygulamasının Analizi}

Filmin senaryosu incelendiğinde 61 sahne ayrımından oluştuğu görülmüştür. Aynı şekilde film izlendiğinde de bu sayının biraz üzerinde kesme tespit edilmiştir. Fakat doğrudan film ekibinden bilgi alınamadıkça tam olarak sayı vermek ve bilgisayar üretimi görüntüleri ve müdahaleleri tespit etmek oldukça güçtür. Bu bölümde bariz bir biçimde fark edilebilen bazı kesme anları ve bunların nasıl gerçekleştirildiği analiz edilecek ve kullanılan yöntemlerin çeşitliliğini ortaya koyan örneklere yer verilecektir. Bu sayede yönetmenin, film üzerindeki kontrolü nasıl sağlayabildiği ve kurgu yoluyla mizanseni nasıl gerçekleştirdiği anlaşılmaya çalışılacaktır.

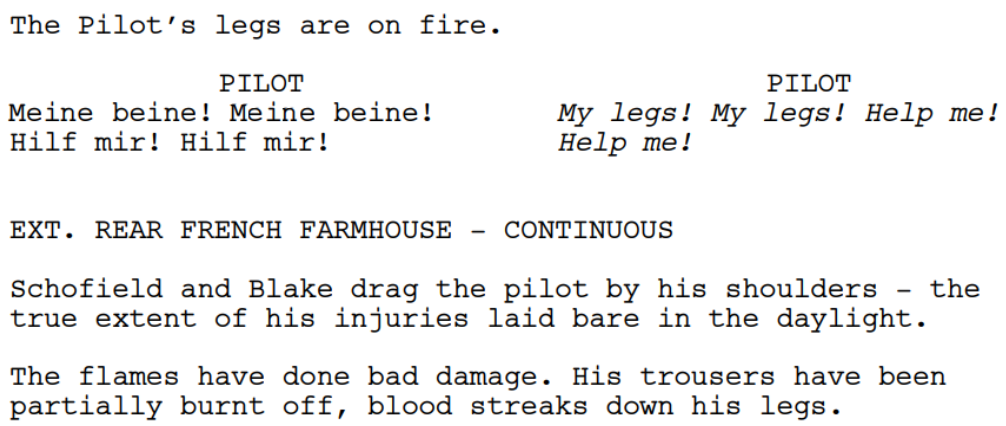

Resim 1. 1917 Filmi Senaryosu.

Filmin Variety.com'da (Donnely, 2020) yayınlanan orijinal senaryosu incelendiğinde senaryo yazma tekniğine uygun olarak sahnelerin ayrımlandığı (özellikle iç/dış mekan şeklinde) ve bu sahne ayrımlarının filmdeki gizli kesme/geçişlerlerle aşağı yukarı uyumlu gerçekleştiği görülmektedir (Resim 1). Sam Mendes ve Krysty Wilson- 
Cairns tarafından yazılan senaryonun kapağındaki notta "bu senaryo gerçek zamanlı olarak gerçekleşecek ve bir an hariç, tek bir sürekli çekim olacak şekilde yazılmış ve tasarlanmıştır" ifadesi de yer almaktadır. Bu detaylar ve film ile ilgili söyleşi, haberler ve tanıtım faaliyetleri açıkça ortaya koymaktadır ki; tüm gizli geçişler en ince ayrıntısına kadar yapım öncesinde tasarlanmıştır.

Filmin yönetmeni Sam Mendes neden bu tür bir yöntemle filmi çekmek istediğini şu şekilde ifade etmektedir; "Karakterle birlikte oradaymışsınız gibi hissetmenizi istedim; onlarla birlikte nefes almanızı, onların yürüdüğü adımlarla yürümenizi istedim. Bunu yapmanın en iyi yolu kesme yapmamak ve izleyiciye oradaymış gibi bir yolu sunmaktı." (Lang, 2019). Ayrıca yönetmen filmin görsel estetiği konusundaki esin kaynaklarından birisinin de çocuklarının oynadığı üçüncü-şahıs nişancı (third-person shooter) türü video oyunlarındaki "büyüleyici, neredeyse hipnoz edici" bulduğu bakış açısı olduğunu ifade etmiştir (Taylor, 2019). Buradaki bakış açısı oyuncunun aksiyonu hemen her zaman oyundaki karakterin omuz üstünden gördüğü ve ondan neredeyse hiç ayrılmayarak öyküyü takip ettiği bakış açısıdır. Bu açıdan değerlendirildiğinde filmde de tamamen aynı olmamakla birlikte buna benzer bir kamera takibinden söz edilebilmektedir. Alternatif olarak kamera her zaman ileri doğru giden karakterleri arkadan değil, bazen onların önüne geçerek önden de takip ettiği gibi, yandan, (bazen) alt açılardan da takip etmektedir. Karakterlerin sabit olduğu anlarda da kameranın hareket ettiği ve kimi zaman onlara yaklaşıp uzaklaştığı, kimi zaman da etraflarında 360 derece döndüğü çekimler de mevcuttur. Bu tür bir sürekli takip, karakterle mekanı ve aksiyonu sürekli bir arada tutan üçüncü-şahıs nişancı türü video oyunlarındaki estetik ile ciddi bir benzerlik ortaya çıkarmaktadır. Özellikle öyküdeki savaş teması da bu tür video oyunlarına aşina olan izleyici için bir tür metinlerarasılık ortaya çıkarmaktadır.

Fade-in ile siyah ekrandan açılan görüntüde tamamen sabit bir planda çiçekli kırları görürüz. Kamera geriye yavaş yavaş açıldığında dinlenen askerleri görürüz ve buranın cephe olduğunu anlarız. Daha sonra ilk talimatı alan Blake ve Schofield yerden kalkar ve kameraya doğru yürürlerken kamera da onları geri geri giderek ikili planda takip eder. Takip planı 2 dakika 40 saniye sürdükten sonra siper içerisinde bir an duraklayarak önlerinden malzeme taşıyarak geçen askerlerin gitmesini beklerler. Burada filmin ilk gizli kesmesi yapılmıştır. Bu geçişi yapmak için birden fazla bilgisayar tekniğine başvurulabilmektedir. Burada kamera askerler tarafından taşınan bir kutu ile tamamen marke olmuştur. Gün ışığı altında aydınlık bir ortam söz konusu olduğu için yapılacak alelade bir kesme işleminde kutunun konumu çok hassas bir şekilde yeniden tekrarlanamayacağı için kesme işlemi göz tarafından algılanacaktır. Bu sebeple en uygun yöntem maskeleme ile önden geçen askerlerin ve kutunun kesilmesi ve ekran tamamen kutu ile kaplı olduğu anda bir sonraki kareye geçilmesidir. 
Tablo 1. 1917 filmi ardışık ekran görüntüleri.
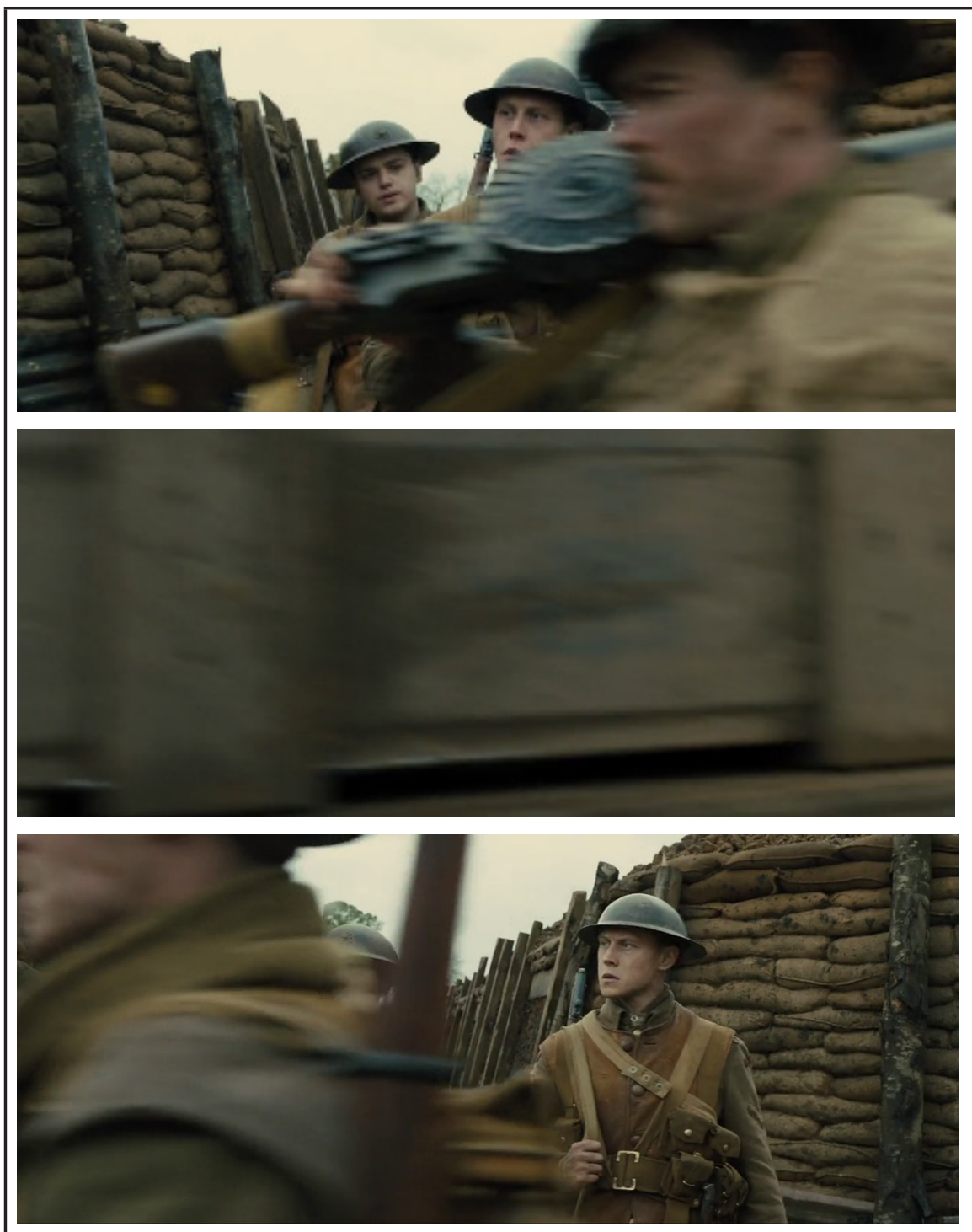

Askerlerin geçişinden sonraki karelerin ilkinde kadraj içerisindeki değişim açıkça görülmektedir (Tablo 1).

Takip planlarında kamera geri geri giderken bir an duraksayıp (mekandaki bir köşe/ dönüş kullanılarak) devam eden oyuncuyu çevrinme ile izler ve bu tekrar takibe devam ederken artık ikiliyi arkadan izlemektedir. Devamında da talimatları veren çavuşun ikilinin omuz üstü çekiminden göğüs plan olarak izleriz. Bu tür değişimler kurgu ile sağlanan açı ve perspektif değişimlerine farklı bir alternatif yaklaşım olarak karşımıza çıkmaktadır. Aynı şekilde oyuncu konumlarının kameraya göre değişimi, yaklaşıp 
uzaklaşmaları ve yer/yön değiştirmeleri ile çekim ölçekleri değişmekte ve yönetmen mizanseni kontrol edebilmektedir.

Filmin yaklaşık 2 dakika 30. Saniyesinde bir başka gizli kesme yapılmıştır. Buradaki geçiş bizi özellikle dış mekandan içe (ve tersi) geçişteki ışık farkı nedeniyle oluşacak teknik zorluğa dikkat etmeye yönlendirmektedir ve bir kesme yapmanın zorunlu olabileceği zaten tahmin edilebilmektedir. İkili karargaha girdiğinde kamera gün ışığından karanlık ve loş bir ortama geçiş yapmıştır. Önceki karenin alan derinliğine bakıldığında kamera diyaframının çok kapalı olamayacağı anlaşılmaktadır -bu durum içeri girerken diyaframın açılması intimalini ortadan kaldırmaktadır-ve bu tip çekimlerde ND (doğal yoğunluk) filtre kullanılmaktadır. İçeriye girildiğinde ise ortaya çıkan ışık farkını tolere etmek için ND filtrenin çıkarılması gerekmektedir. Sırf bu nedenle dahi kesme yapılması bir zorunluluk haline gelmektedir (Tablo 2).

Tablo 2. 1917 filmi ardışık ekran görüntüleri

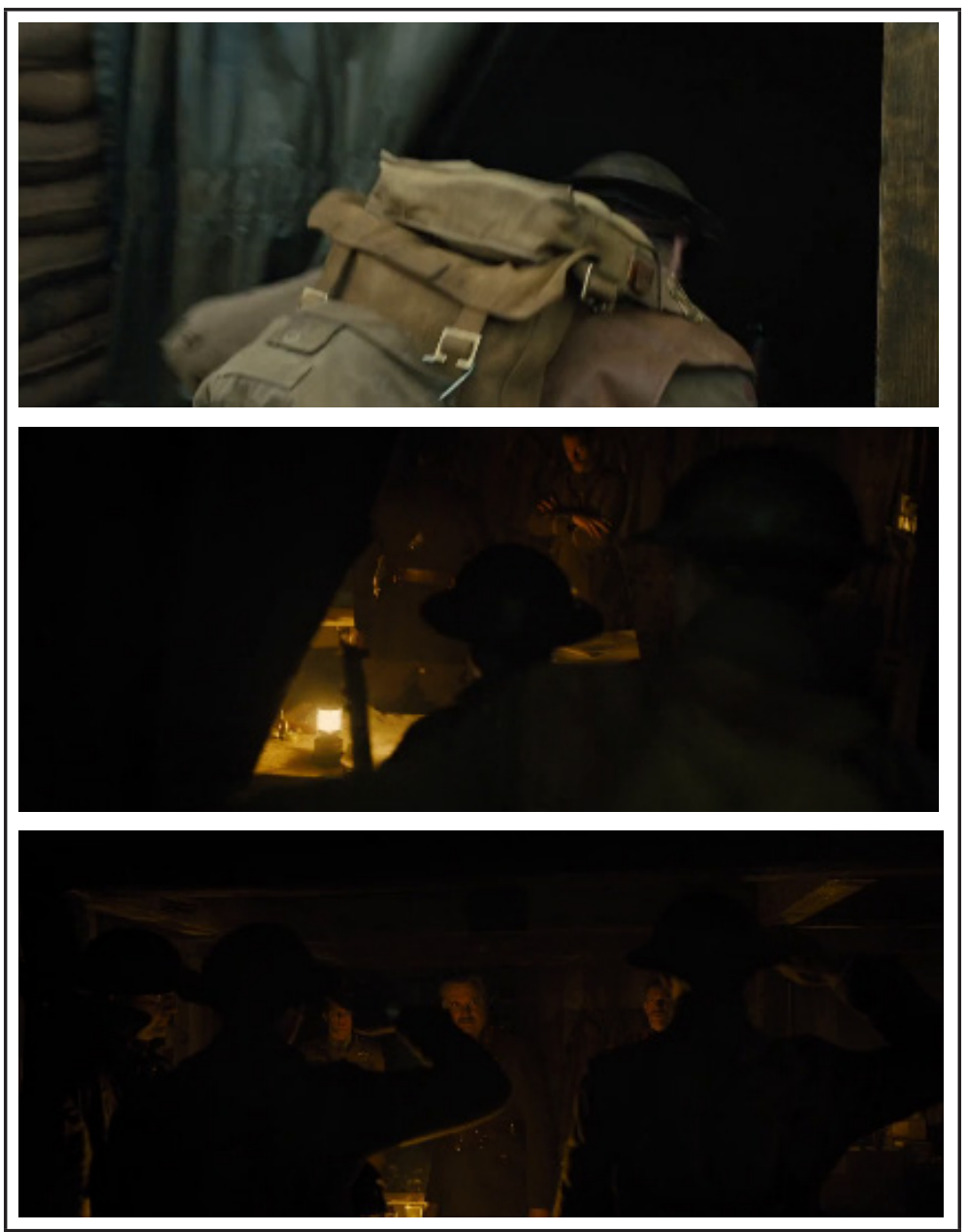


Filmin bu noktasındaki değişime bakıldığında önceki sahne ile sonraki sahne arasında objektifin odak uzunluğunun da değiştiği (daha dar açılı objektife geçilmiştir) göze çarpmaktadır. Objektifin odak uzaklığının değişmiş olması yine yönetmenin perspektif ve boyut üzerindeki denetimine olanak sağlarken, mizansen içerisinde hiyerarşik bir yerleşim ile bakışı yönlendiren bir etki elde edebilmesini sağlamaktadır. Ayrıca zor görevi veren komutanın tekli planına geçiş de yine bu yöntem sayesinde mümkün olmuştur (Resim 2).

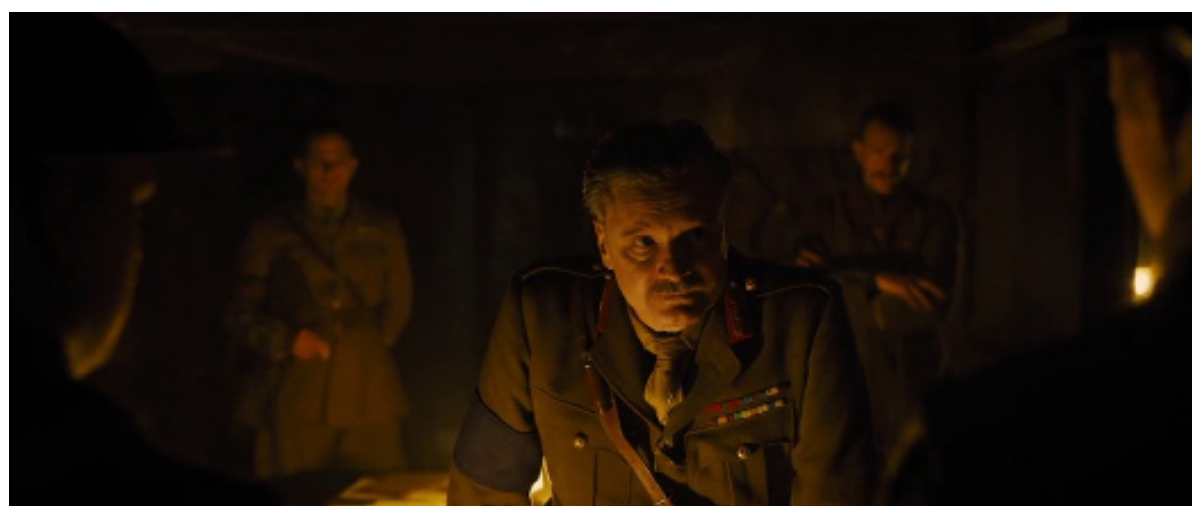

Resim 2. 1917 filmi ekran görüntüsü.

Sahnenin devamında kamera ileri doğru devam eder ve Blake ve Schofield sahnedeki yerlerini değiştirerek tekrar kameranın karşı açısına geçerler. Sahnenin bitiminde ise karargahtan çıkışta yine benzeri bir kesme yapılmıştır. Schofield'ın sırt çantası kadrajı tamamen kapatmakta ve ekranın karardığı an kurguda rahat bir kesme noktası sağlamaktadır (Tablo 3).

Tablo 3. 1917 filmi ardışık ekran görüntüleri.

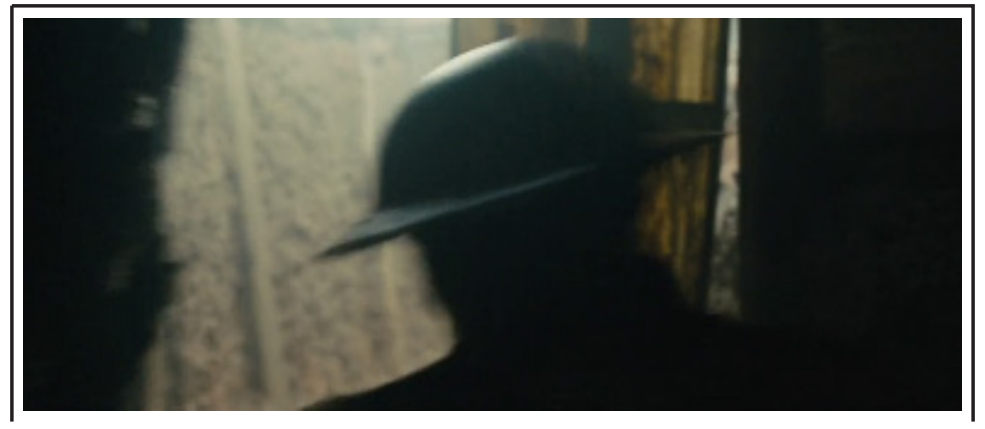




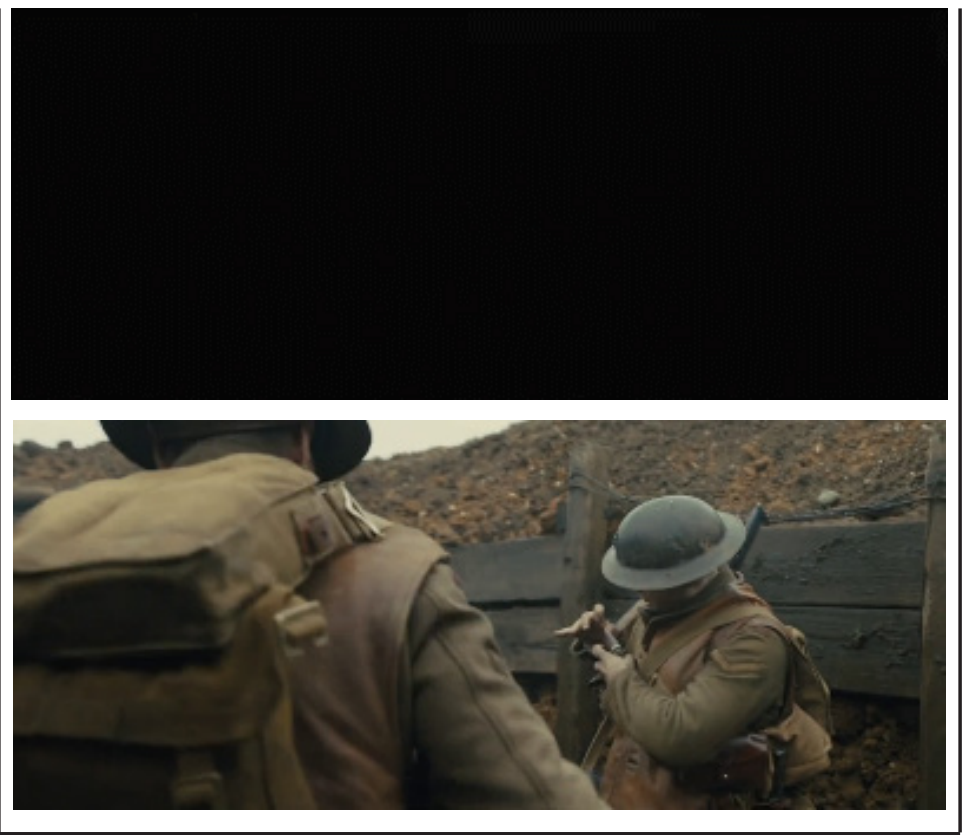

İkili siper içerisinde koşar adımla ilerlerken diğer askerlerin kalabalığını yararak ilerlemektedir. Bu esnada kameranın takibi de doğal olarak hızlanmış zaman zaman arkadan, zaman zaman önden takip ederken kamera önünden diğer askerlerin hızlıca geçtiği bir anda yine gizli kesme yapılmıştır (Tablo 4).

Tablo 4. 1917 filmi ardışık ekran görüntüleri.
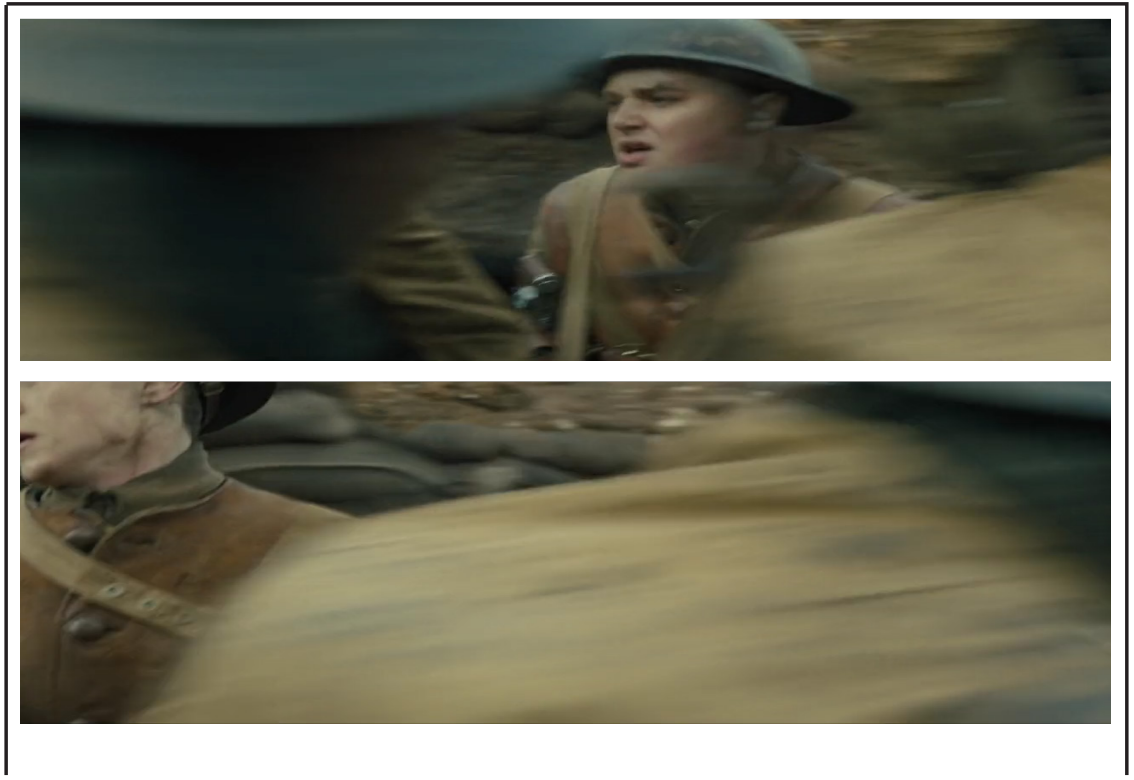


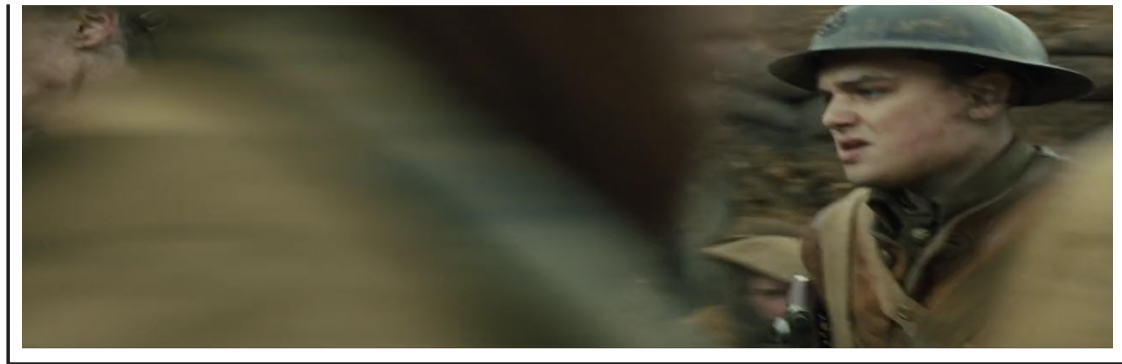

Bu gizli kesmelerin filmin akışı sırasında kolay kolay gözlenemediğini ancak kare kare yeniden oynatım ve tekrar tekrar izleme ile fark edilebildiğini belirtmek gerekmektedir. Bu sahnelerde filmin dramatik akışına uygun olarak temponun arttığı gözlenmektedir. $\mathrm{Bu}$ tempo artışı ise oyuncuların hızlanmasına eşlik eden hızlı kamera takibi ile de desteklenmektedir.

Tablo 5. 1917 filmi ardışık ekran görüntüleri.

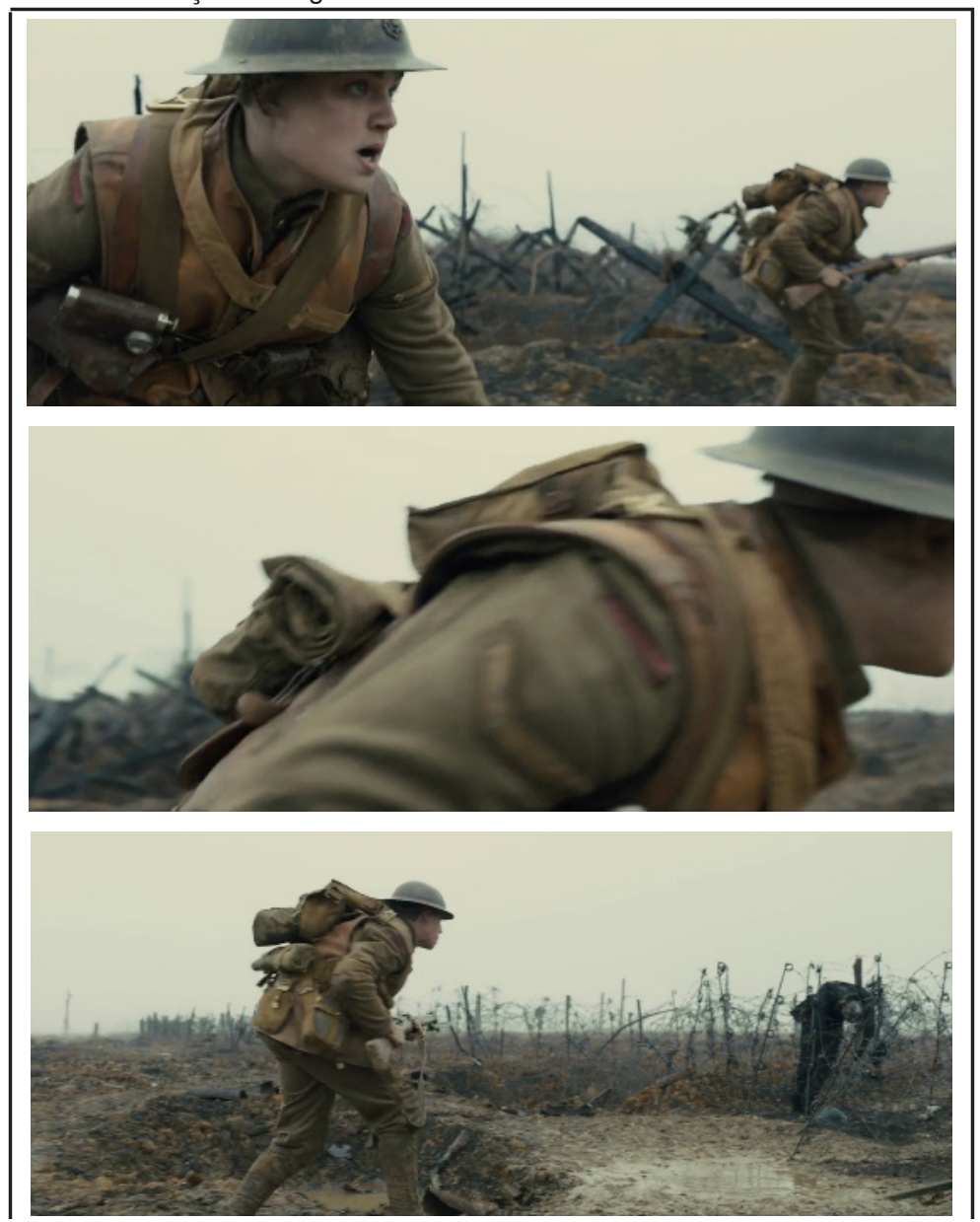




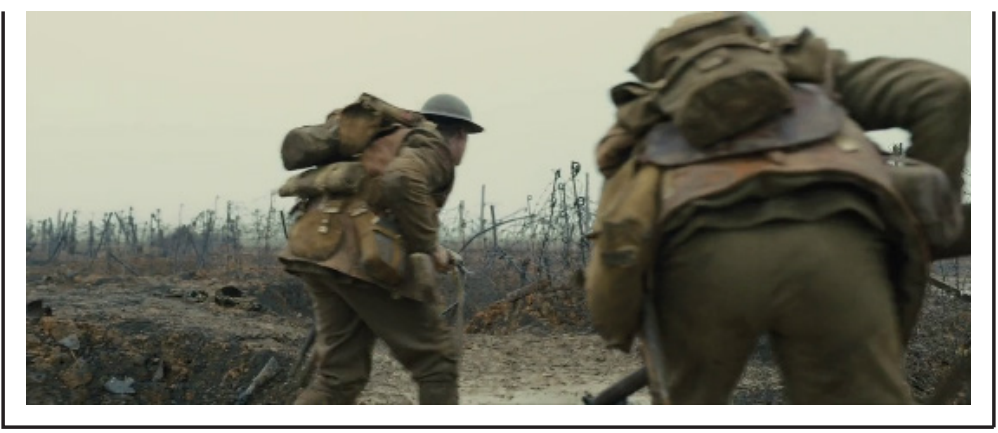

(Yaklaşık 17.00'de) İkili tedirgin bir şekilde düşman hattına ilerlerken, Blake karakteri onları takip eden kameraya yaklaşır ve Schofield karakterini tamamen örtecek şekilde kadrajı kaplar daha sonra kadrajdan çıkar ve sonunda tekrar girer. Burada maskeleme ve rotoskopi yöntemiyle kesme gerçekleştirilmiştir. Benzer geçişlere filmin birkaç noktasında daha rastlanmıştır, özellikle bulutsuz gökyüzünün fonda olduğu ve karakterlerden birinin ya da her ikisinin de kadrajı terk ettiği yerlerde yine bu tür bir geçiş gerçekleştirilmiştir (Tablo 5).

Kesmelerin zamanlaması ve yeri; setin fiziki şartları ve kamera hareketinin kesintisiz sağlanması dışında, oyunculara makyaj, özel efekt (kan vb.) gibi müdahalelerin yapılabilmesi, figüranların yerini alması, ışık ve lens değişimi ya da oyuncuların diyaloglarını unutmaması ve daha çoğaltılabilecek bir çok sebeplere göre belirlenebilmektedir. Bunların her biri yine yönetmenin envanterindeki araçlar olarak yerini almaktadır.

Filmin yaklaşık 19. dakikasında yer alan bir kesmede ise tamamen bilgisayarda üretilmiş bir çeşit dijital dublör (digital double) ile iki plan arasında kesintisiz bir geçiş sağlanabilmiştir. Buradaki geçiş filmin görsel efektlerini yapan şirket tarafından yayınlanan tanıtım amaçlı videolardan (MPC Film, 2020) ve yine filmin görsel efekt süpervizörü ile yapılan söyleşilerden (Hofferman ve Sarto, 2020) elde edilen bilgiler sayesinde fark edilmiştir. Aksi halde izleyici tarafından fark edilmesi neredeyse imkansız olan bu geçişler gerçek görüntü ile bilgisayar üretimi görüntü arasındaki farkın bazı durumlarda son derece belirsiz hale gelmesine örnek teşkil etmektedir (Resim 3). 


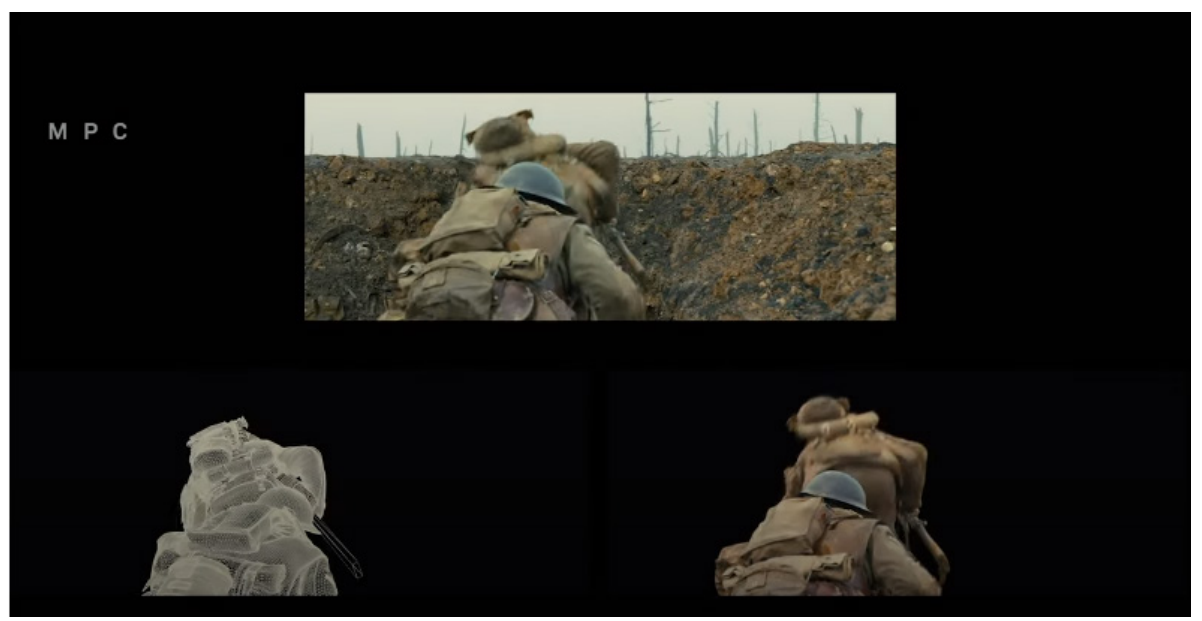

Resim 3. MPC Film - 1917 VFX Breakdown - Youtube Ekran Görüntüsü

Filmin görsel efekt süpervizörü Guillaume Rocheron, filmde geçişleri sağlayabilmek için kolaya kaçmadıklarını ve zorlama kamera hareketlerinden kaçındıklarını ifade etmiştir. Geçmişte yapılan filmlerle kıyaslama yapan Rocheron, eskiden kameranın kolayca geçiş yapılabilmesi için sıklıkla bir mimari yapı vb. tarafından marke edilmesi gibi sıradanlaşmış yöntemlerle yapılan gizli kesmeler yerine bu filmde çok geniş türde yöntemleri bir arada kullandıklarını belirtmiştir. Böylelikle hem teknik hem de artistik açıdan doğal görünen bir sonuç elde ettiklerini söylemiştir (Hofferman ve Sarto, 2020). Bu ifadeler bize Hitchcock'un Rope'da uyguladığı yöntemleri hatırlatmaktadır. Artık teknolojinin sunduğu olanaklar ile zorlama ve filmin doğallığını bozacak kamera hareketlerine gerek kalmadan da gizli geçişler yapılabilmektedir. Filmde dijital dublörlerin kullanıldığı başka sahnelerde bulunmaktadır. Örneğin filmin sonlarına doğru Schofield karakterinin nehre atladığı sahnede de benzeri bir teknikten yararlanılmıştır (Tablo 6). Dijital dublör kullanımı yalnızca bu sahnelerle sınırlı kalmamış, nehirde karakterin batıp çıkarak ilerlediği ya da şelaleden aşağı düştüğü tehlikeli anlar da aynı teknikten yararlanılmıştır. 
Tablo 6. MPC Film - 1917 VFX Breakdown - Youtube Ekran Görüntüsü
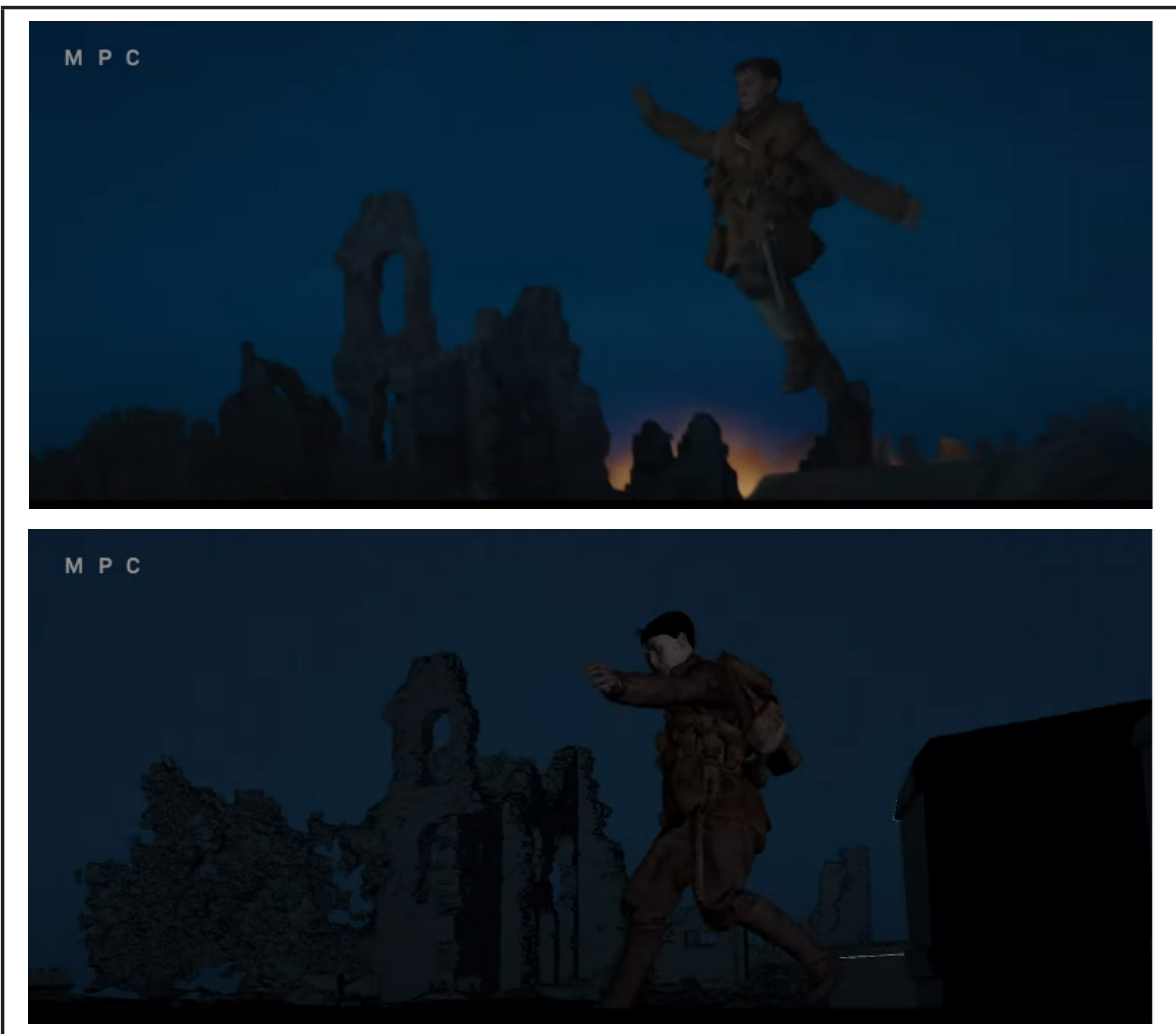

Rocheron, 1917 filmindeki kesmeler/geçişler için "dikiş" ifadesini kullanmıştır. Zira filmin \%97'sinde az ya da çok miktarda bilgisayar dokunuşu olduğunu belirtmiştir. Bu müdahalelerin çoğunluğu ise dijital set genişletmeleri ve görüntüdeki istenmeyen obje/ kısımların silinmesinden oluşmaktadır (Hofferman ve Sarto, 2020). Yani gizli kesmeler basitçe bir "cut/kesme" geçiş ile değil kombine tekniklerin bir arada kullanılması ile önceki ve sonraki planın parçalarının birbirine sarktığı karmaşık geçişlerdir. Araştırmada bu gizli kesme anları için geçiş demek daha doğru olacaktır. Çünkü basitçe iki kare arasında kesme yapmaktan daha karmaşık bir "birleştirme" söz konusudur.

Filmde kamera hareketleri aksiyon filmlerinde sık rastlanan sert el kamerası (handheld) tekniğiyle değil yumuşak bir şekilde sürekli süzülen bir akış şeklinde gerçekleştirilmiştir. Kameranın bu neredeyse sürekli hareketli hali oyuncular sabit olduğunda da sahnenin temposuna uygun biçimde devam etmektedir. Kameranın karakterler etrafında 360 derece dönüşleri gibi daha belirgin hareketlerine ise genelde karakterlerin kendi duygusal yoğunluklarının zirveye ulaştığı anlarda rastlanmaktadır (Tablo 7). 
Tablo 7. 1917 filmi ardışık ekran görüntüleri.
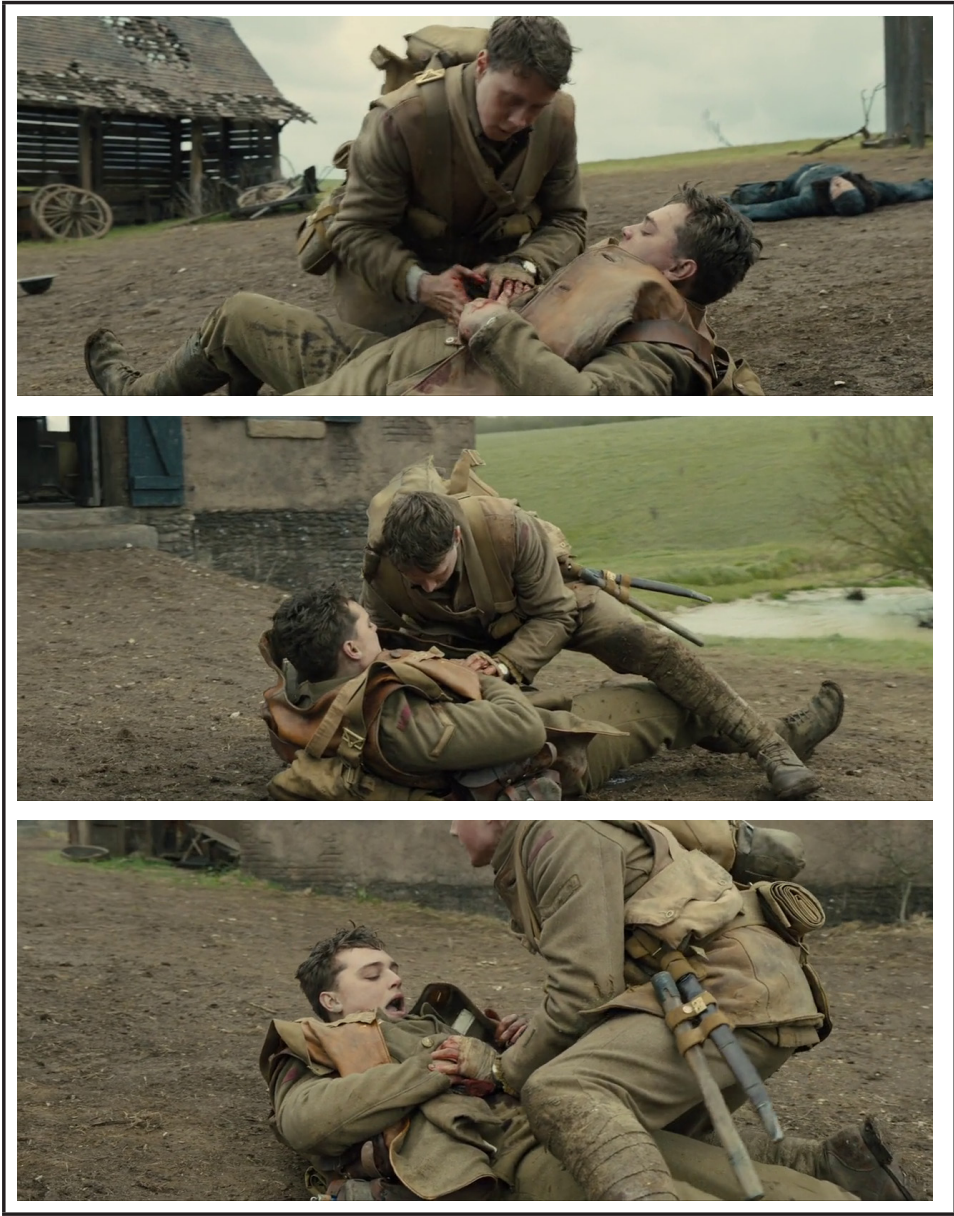

Buradaki kamera hareketi karakterlerin çaresizliği içerisinde zamanın hızla akmasını vurgulayan bir duygu aktarımına hizmet etmektedir. Kurgu yapılmadan, zamanda eksiltme yapmadan kamera; karakterin gerçek zamanlı bir biçimde ömrünün son anlarını yaşamasına önce telaşı, daha sonra ise olanı biteni kabullenmiş bir biçimde sakin ve durağan şekilde eşlik etmektedir. Bu tür kamera hareketleri karakterleri sürekli aksiyonun merkezinde tutan ve çevreyle ilişkilerini de kuran üçüncü-şahıs nişancı (third-person shooter) türü video oyunlarına da benzemektedir. Özellikle karakterin omuz üstünden takip edildiği bu oyunlara benzer şekilde filmdeki karakterin yöneldiği yeri gösteren ve onunla birlikte ilerleyen kamera açıları da izleyicinin görsel hafızasında bu tür bir ilişki kurmasına neden olmaktadır (Resim 4). 


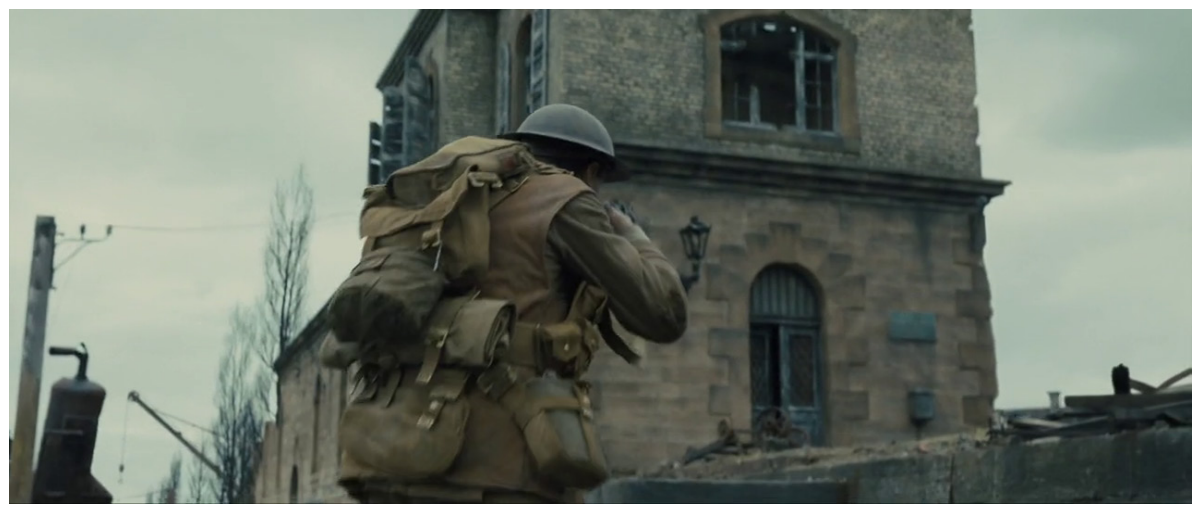

Resim 4. 1917 filmi ekran görüntüsü.

Filmdeki zamansal sürekliliğin kıııldığı tek anda Schofield karakteri bir Alman askeri ile kısa mesafeden çatışmaya girer ve aynı anda iki el silah sesi duyulduktan sonra Schofield geriye doğru merdivenlerden düşer ve ekran kararır. Bu noktada Schofield'ın başına ne geldiği izleyici tarafından bilinmez bir haldedir. Ekranın kararması alışıldık bir zaman geçişi belirteci ya da sahne sonundan çok karakterin bilincini yitirdiğini, gözlerinin kapandığını belki de öldüğünü ifade etmektedir. Filmin sürekliliğini bozmak pahasına bu kararmayı (fade-out) yapan yönetmen verdiği bir röportajda (CinemaBlend, 2020) bunun "öyküde, filmin atmosferinde ve karakterin algı boyutunda beklenmedik-keskin bir değişimi ifade etmesini umduğunu" söylemiştir. Gerçekçi bir atmosferden rüya ya da halüsinasyon türü sürreal bir atmosfere geçişi amaçladığını ifade eden yönetmen izleyiciyi merakta bırakmayı da amaçladığını ifade etmiştir. Uzun süren siyahtan sonra tekrar görüntü açıldığında hem izleyici hem de Schofield aradan ne kadar zaman geçtiğini bilmemektedir. Bu durum buradaki kararmanın işlevini de filmin genel akışı ile belli ölçüde bütünleştirmektedir. Zira izleyici Schofield ile gerçek zamanlı bir şekilde öyküyü yaşamaktadır. Ancak ne olursa olsun kararma öyle ya da böyle kesintisiz tek çekim akışını bozmuştur. Çünkü izleyici sinemada bu kararma ve aydınlanma türü geçişlerin "koduna" hakimdir. Yönetmen tarafından planlanmış da olsa, gerçek zaman ile film zamanı arasında bir kırılmaya yol açmaktadır.

Filmde bir objenin ekranı tamamen kaplamasına benzer biçimde bir patlama sahnesinde dumanların ekranı kaplaması tipik bir gizli kesme (geçiş) noktasını oluşturmaktadır. Tıpkı tamamen karanlık bir görüntü ya da kameranın bulutsuz mavi gökyüzüne çevrilmesi gibi homojen bir kesme anı sunan bu tür geçişler gizli kesme yapmak için bilindik fırsatlardır. Kesme ise, gerçek anlamda bir kesme (cut) olmayıp zincirleme (dissolve) ya da dumanların görsel efekt (VFX) olarak üretilmesi ile de bir kareden daha fazla zamana yayılmış bir geçiş olabilmektedir (Tablo 8). 
Tablo 8. 1917 filmi ardışık ekran görüntüleri.

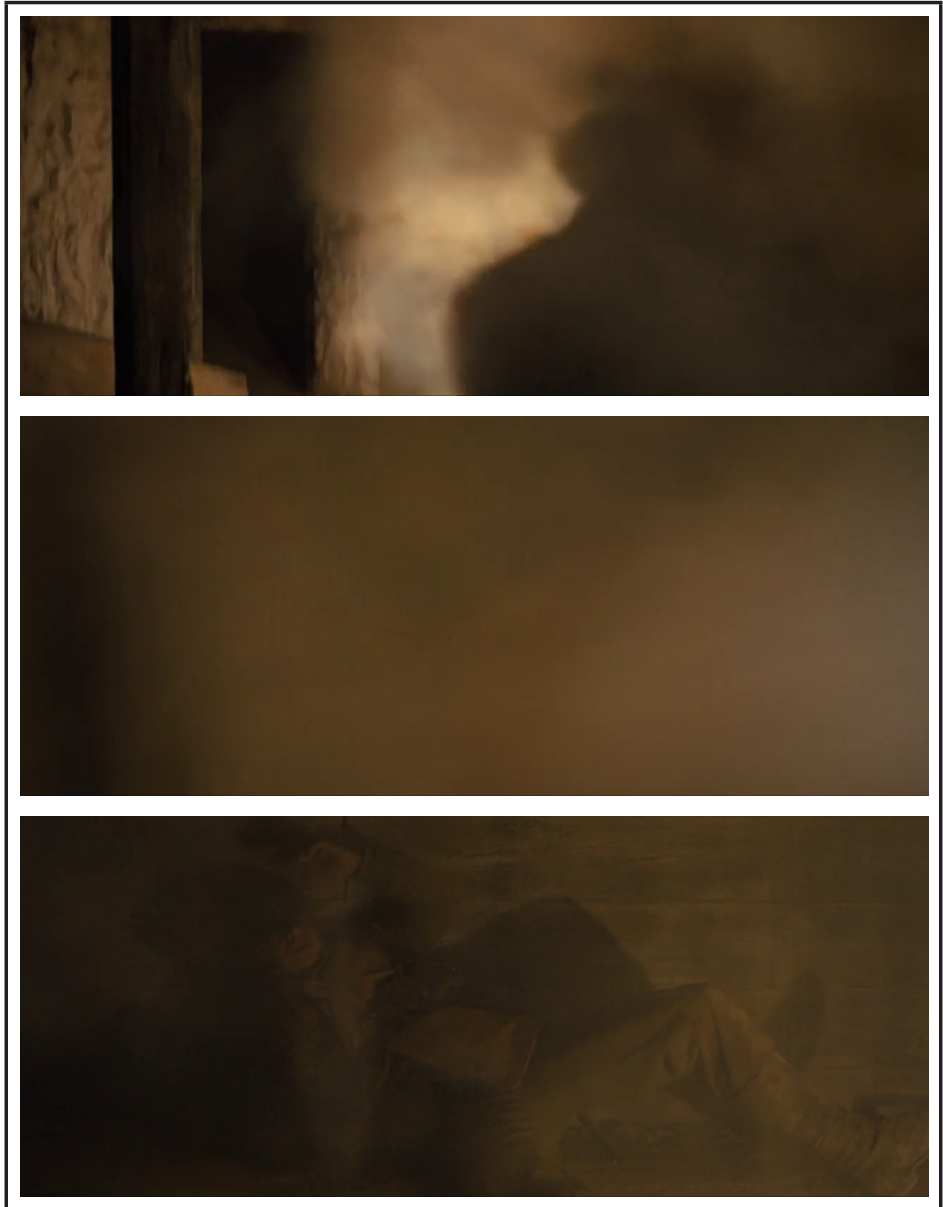

Çerçevenin sınırlarını aşan ve bu haliyle ekranı bölen mimari yapılar ve objeler de gizli kesme için çok elverişli bir nokta oluşturmaktadır (Tablo 9). 
Tablo 9. 1917 filmi ardışık ekran görüntüleri.
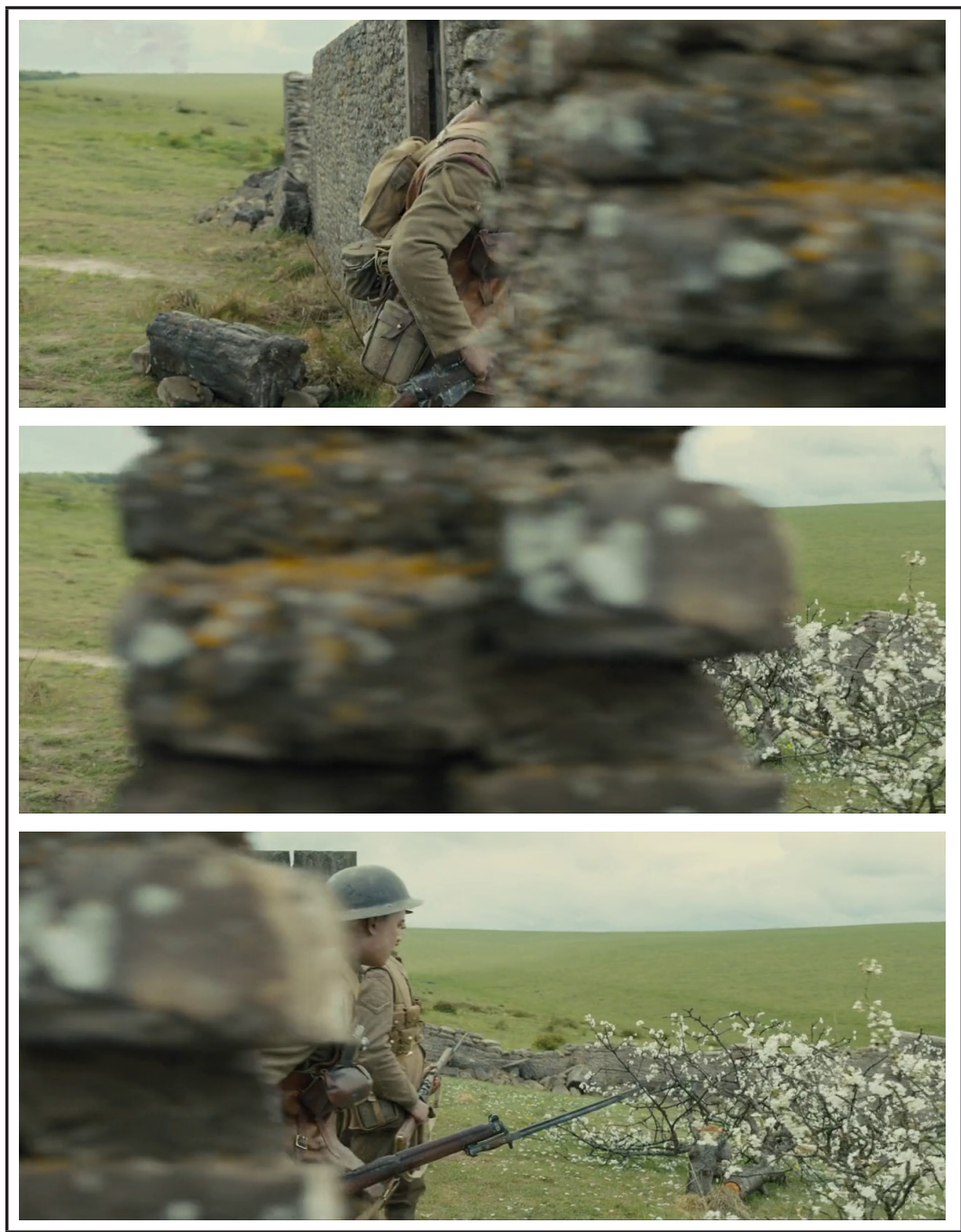

Filmdeki diğer geçişler de örneklerde gösterilen geçişlerin varyasyonları ile gerçekleştirilmiştir ve bu araştırma kapsamında tamamına yer vermek mümkün değildir. Tekrar belirtmek gerekirse, filmdeki tüm gizli müdahaleleri tespit etmek olanaksızdır. Ancak, örnekleri gösterilen alternatif yöntemlerle, esnek ve sık bir biçimde fakat görsel sürekliliği sekteye uğratmayan bu geçişler, yönetmenin mizansen üzerindeki kontrolünü ve görünmez bir şekilde nasıl kurgu yapabildiğini ortaya koymaktadır. 


\section{Sonuc}

Hitchcock'un Rope'undan 71 yıl sonra çekilen 1917 filmi, teknolojinin ulaştığı seviye ve bilgisayarların hiç olmadığı kadar sinemaya dahil olmasıyla birlikte yönetmenlerin "elininin güçlendiğini" ortaya koymaktadır. İzleyiciye hiç fark ettirmeden yapılabilen "gizli” geçişlerin sıklığı ve çeşitliliğiyle, tek plan gibi görünen filmlerin de "belli oranda" kurgulanabildiğini görülmektedir. Bu haliyle 1917filmi sinemanın ilk yıllarındaki durağan kamera konumuyla çekilmiş sahnelerdeki oyuncu merkezli ve tiyatro estetiğine sahip filmler ile yoğunlaştırılmış aksiyon devamlılığı kurgusuna dayalı günümüz ana akım filmlerinin arasında, farklı bir sinema deneyimi olarak karşımıza çıkmaktadır.

1917 filminde, çekilen sahnelerin filmin kurgucusu tarafından çekimin hemen ardından kabaca birleştirilebilmesi (kurgulanabilmesi) hatta ses ve müzik düzenlemesinin dahi kaba taslak yapılabilmesiyle; yönetmen çekilen sahnenin temposunu, oyuncuların performansını, ritmi ve oluşan film atmosferini anında kontrol edebilme ve bu yönde filme müdahalede bulunabilme imkanına kavuşmuştur. Sahnelerin birbirine pürüzsüz biçimde bağlanabilmesi dışında kronolojik olarak çekilen (öyküye uygun bir biçimde gerçek zamanlı çekildiği için) sahnelerin arasındaki duygu ve atmosfer de sonucu anında görebilme imkanı sayesinde yönetmenin denetiminde kalabilmiştir. Bu sayede film çekilirken bir yandan da aşama aşama ortaya çıkmıştır.

Bu noktada özellikle gerçek anlamda tek plan olarak çekilen filmlerle bir kıyaslama yapmak yerinde olacaktır. Hem örneklerde değindiğimiz Russian Ark ve Victoria filmleri hem de bu yöntemle çekilmiş diğer filmlerde yönetmenin film üzerindeki hakimiyeti hatta "yönetmen" olarak katkısı tartışmalı bir hal almaktadır. Bu tip filmlerle ilgili olarak; saygın festivallerden medyaya, sinema izleyicilerinin yorumlarından sosyal medya paylaşımlarına kadar birçok yerde yalnızca tekniğin öne çıkması alışıldık bir durum haline gelmiştir. Yönetmenin çok iyi ve sıkı bir biçimde prova yapabilmekten başka filmin ayrıntılarına müdahale şansı neredeyse kalmamaktadır. Bu haliyle biçimsel açıdan olmasa da uygulama açısından tiyatroya yakın bir yaklaşım ortaya çıkmaktadır. Oyuncu performansları ve bu performansları görüntüleyen kameramanın performansı, yönetmenin güçlü kontrolünün dışına çıkmakta ve "yönetmenin filmi" olgusunu sorgulatmaktadır. Victoria filminde yönetmenin istediği performansa yakın olana kadar filmi en fazla 3 kez baştan sona tekrar çekebilmesiyle (bütçe ve zaman kısıtlaması nedeniyle) istediği sonuca ne kadar yaklaşabildiği tartışmalıdır. Yine Russian Ark filminin yalnızca kameramanına ödül verilmesine tepki gösteren yönetmen Sokurov da filmin sanatsal yaratıcısının kendisi olduğunu vurgulama intiyacı hissetmiştir. Ancak filmde yer alan binlerce figüranın hatalar yapmasından (filmde kameraya bakarak dördüncü duvarı yıkan ve gözlerini bir anda kaçıran figüranlar dahi görünmektedir), film sonrasındaki kadraj ve hız düzeltmelerine kadar anlaşıldığı üzere, çekim esnasında film yönetmenin kontrolünden çıkmaktadır.

Dolayısıyla tek plan gibi görünen bir film yapmak ile gerçekten tek plan bir film yapmak arasında biçem bakımından gözle görülür bir fark olmayabileceği gibi, gizli geçişler/ kesmelerle tek çekim gibi görünen filmlerde yönetmenin filme müdahalesi sadece tasarım aşamasında kalmayıp, belli ölçüde de olsa hala biçeme yön verebilmektedir. 
Tek plan gibi görünen filmlerde yine gerçek zamanlı ilerleyen bir öykü ihtiyacı doğmaktadır. Zira kurgu (gizli kesme) olsa da, film zamanı ile gerçek zaman birbirine denk ilerlemektedir. Öyküdeki gerçek zamanlı olma durumu ise; sinemasal zamanın yönetmen tarafından istendiği gibi uzatılıp kısaltılmasına ya da zamanda/ mekanda ileri geri sıçrama imkanını ortadan kaldırmakta ve öykülemede tek düze bir doğrusallık yaratmaktadır. Gerçek zamanlı bir hikayeyi dramatik yapıya büründürmek ise yönetmenin tercihi ile ilgilidir ve anlatım biçimi ile öykü uyumlu olduğu sürece sinemanın zengin potansiyelinin bir parçası olarak yerini almaktadır. 1917 filminin senaryosu yönetmen (bir başka senarist ile beraber) tarafından sürecin başından itibaren bu şekilde çekilmek üzere yazıldığından ve yapım bu şekilde tasarlandığından öykü ile biçim arasında zorlama olmayan anlamlı bir uyum olduğu söylenebilmektedir.

1917 filmindeki tek kararma (fade-out) geçişi, zamanda ileri gitme işlevi görmesinin yanında karakterin kendinden geçmesi hali ile birbiri içine geçmiştir. Öyküde ve filmin atmosferinde bir değişim anına tekabül eden bu kararmanın yönetmeninin bilinçli bir tercihi olduğu ortadadır. Filmi tek çekim gibi çekmesinin nedenini "izleyicinin karakterin adımlarıyla yürümesini istedim, filmin içine dahil olmasını istedim" şeklinde açıklayan yönetmenin tek çekim akışını bu şekilde bozması yönetmenin varlığını da ilk kez ortaya koymaktadır. Bu kararmada eğer amaç tek çekim gösterisini sürdürmekse, hem senaryoya hem de öyküye müdahale edilebilirdi. Yönetmen, Schofield'ın hikayesini izlerken izleyiciye filmin yaratıcısını da hatırlatmaktadır. Başka bir açıdan değerlendirildiğinde ise ister alışıldık devamlılık kurgusu ile olsun, isterse tek çekim halinde olsun, filmde izleyicinin özdeşleşmesini kıracak bir tercihte bulunulmadıktan sonra bu tip bir kararma filmin izleyici üzerindeki genel etkisini bozmamaktadır.

Yönetmenin elindeki gelişmiş teknik imkanlar sayesinde, tek çekim gibi görünen bir film yapmak için dar bir alana sıkışmış stüdyolardan çıkıp, çok geniş platolara ya da gerçek iç/dış mekanlara açılmak daha kolay hale gelmiştir. 1917 için açık havada inşa edilen devasa platonun her bir adımı ince ince hesaplanmış, çekimlerin yapıldığı hava koşulları (bulutlu hava) da çekimlerin sorunsuz yapılabilmesi için kollanmıştır. Bu sayede film gerçekçi bir şekilde mekânsal algıyı oluşturabilmiş, kameranın uzun takip planları yapabilmesini de doğal bir nedene kavuşturmuştur. Bu açıdan teknolojinin, plan-sekansları kameranın ulaşabildiği her yerde mümkün kıldığı görülmektedir. Bunun film biçemi açısından etkisi ise filmsel zaman ve uzamın kesintiye uğratıl(a) mamasına rağmen öyküyü ilerletmek için intiyaç duyulabilecek olan devinimin mekana yayılabilmesi olmuştur.

Kameranın zorlama hareketler yapmadan karakterleri ve olayları kesintisiz görüntüleyebilmesi ve mekanda "kendisini hissettirmeden" dolaşabilmesi tek çekim illüzyonunun oluşturulmasına katkıda bulunmaktadır. Kamera taşıma araçlarının gelişmesi ve kameranın bir platformdan başkasına yumuşak ve kesintisiz biçimde aktarılabilmesi mekânsal sınırlamaları ortadan kaldırmıştır. Kamera hareketlerinin uzaktan kontrol edilmesini sağlayan kablosuz iletim teknolojileri de hem yönetmenin hem de görüntü yönetmeninin görüntü üzerindeki hakimiyetini artırmış ve bu da sonuca yansımıştır. Yine tek plan olarak çekilen filmlerden farklı olarak düzensiz kamera hareketleri ya da inisiyatifin tamamen kamera operatöründe olduğu durumlar aşılabilmektedir. Filmsel zaman gerçek zamana paralel olsa da, hızlı ya da yavaş 
ilerleyen devinime hemen her koşulda ayak uydurabilen hareketli kamera sayesinde tempo yönetmenin kontrolünde olmaktadır. Bu gelişmeler filmi aşama aşama yönetmenin idealine yaklaştırmaktadır.

Gizli kesmeler arasında kalan uzun çekimler tıpkı Fransız Yeni Dalgası'ında rastlanan örneklerde olduğu gibi yönetmenin üslubu ve tercihi olabilmektedir. Bu noktada Hitchcock'un Rope hakkında söylediği "bir daha yapmam" ve "filmler kurgulanmalıdır" şeklindeki görüşlerinin bugünün koşullarında aynı kalıp kalmayacağı da soru işaretidir. Burada aksiyon devamılığına dayalı kurguyu (açı-karşı açı olarak da adlandırılan) kasteden Hitchcock'un, Rope'da denediği yönteme benzer biçimde 1917 filminde; karakterleri takip eden kamera bazen bir oyuncuyu ya da objeyi yakın plan gösterebilirken bazen de geniş bir çekimi doğal bir şekilde gerçekleştirebilmektedir. Bunu yaparken hem oyuncuların devinimi hem de kameranın hareketi ile birlikte mizansen dinamik bir biçimde oluşturulabilmektedir. Mekanla ilişki kurmayı sağlayan kamera ve oyuncuların karşılıklı hareketi dışında, filmde karakterlerin yoğun duygu değişimi yaşadığı anlarda kameranın oyuncu etrafında 360 derece döndüğü hareketler de filmde yer almaktadır. Bu hareketlerin yumuşak ve akışkan bir biçimde yapılması sahnenin doğallığını kırmadığı gibi karakterleri çepeçevre saran bir bakış sunmakta, bu yolla dramatik etkiyi de artırabilmektedir. Sonuç olarak kesme yapmadan da izleyiciye bir duyguyu ve düşünceyi aktarmak mümkündür. Kamera hareketlerinin oyuncularla beraber sürekli bir devinim içerisinde olması da video oyunlarına has sürükleyici (immersive) bir izleme deneyimi ortaya çıkarmıştır.

Bazı unsurların tamamen dijital olarak sahneye yerleştirilmesi (dijital sahne genişletmeleri, obje yerleştirme vb.) dışında istenmeyen unsurların da temizlenmesi ile esnek bir biçimde gerçekleştirilen manipülasyonlar ile tek çekimden kaynaklanabilecek zorluklar da aşılabilmektedir.

Hollywood sinemasında işlenen destansı savaş öykülerinde kullanılan kamera ve formatın yapımın ihtişamına gölge düşürmeyecek şekilde tercih edildiği günümüzde, sadece tek plan ya da uzun çekim yapabilmek için görüntü niteliğinden ödün vermek, eğer makul bir estetik anlayış içerisinde karşılık bulamazsa anlamsız bir tercih olma tehlikesini beraberinde getirmektedir. Yani günümüzün "kusursuz" dijital görüntü peşinde koşan izleyicisine kalitesiz bir görüntüyü izah etmek gerekebilmektedir. Bu açıdan 1917de kullanılan kamera formatının (Büyük Format - Large Format) da Hollywood geleneğini sürdüren nitelikte günümüz standartlarının gelişmiş bir örneğidir. Gerçek tek plan olarak çekilmiş filmlerde ise bu kaliteden ödün verilmek zorunda kalındığı (amatör, yarı-profesyonel ya da küçük sensörlü kameralar...) görülmektedir. Dolayısıyla yeni geliştirilen bir kameranın da (Alexa Mini LF) bu tür bir yapımın gerçekleştirilebilmesinde payı olması, bizi yine teknik gelişme ve sinema ilişkisini hatırlamaya itmektedir. Kameranın kendisi dışında kamera taşıma platformlarındaki gelişmeler de bunun önemli parçasıdır.

1917 kesme yapmadan yapılan uzun çekimler ve plan-sekansların fark ettirmeden birleştirilmesiyle tek çekime dönüştürülmüş bir film olarak ortaya çıkmıştır. Doğaçlamaya yer vermeden, sahne üzerindeki kontrolü tamamen oyuncuya ya da kameramana devretmeden de tek çekim gibi görünen bir film yapılabilmiş ve yine tek çekim filmlerin 
görsel estetiğinden bir şey kaybedilmemiştir. Tek çekim bir film yapmak ise filmin yönetmeninin üslubu ile ilgilidir ve sinema gerçeklik ilişkisi bakımından hangisinin daha makbul olduğu gibi bir tartışmanın ucu açıktır. Hareketli kamera ile birleşen bu teknik, yoğunlaştırılmış devamlılık kurgusuna alternatif bir film biçemi oluşturduğu gibi tekniğin imkanlarından yararlanılarak ulaşılan noktanın hala yeni anlatı biçimleri yaratma potansiyeli olduğunu göstermiştir.

\section{Kaynakça}

Abisel N., Eryılmaz T. (2014). Sinemanın Çağdaşlaşması: Yeni Gerçekçilik, Yeni Dalga. Derleyen: Murat İri, ss.24-62. Der Kitabevi.

Akyürek, F. (2004). Senaryo Yazarı Olmak. MediaCat.

Arnheim, R. (2002). Sanat Olarak Sinema. Çev: Rabia Ünal, Öteki Sinema.

Barnes, H. (2016). How Sebastian Schipper created a one take thriller that surpassed Hitchcock. https://www.theguardian.com/film/2016/mar/24/sebastian-schipper-thriller-victoria--interview, Erişim tarihi: 14.07.2020.

Bonitzer, P. (2006). Kör Alan ve Dekadrajlar. Metis.

Bordwell, D. (2008). Yoğunlaştırılmış Devamlılık Kurgusu: Çağdaş Amerikan Sinemasında Görsel Üslup. Çev: Gürhan Topçu, ss.144-182, Sinema: Tarih/Kuram/Eleştiri. Ed: Seçil Büker, Gürhan Topçu. Gazi Üniversitesi İletişim Fakültesi Basımevi.

Brown, B. (2011). Sinematografi: Kuram ve Uygulama. Çev: Selçuk Taylaner, Hil Yayınları.

Büker, S. (1989). Film ve Gerçek. Anadolu Üniversitesi Eğitim Teknolojisi ve Yaygın Eğitim Vakfı - Yayınevi.

Büker, S., Onaran, O. (1985). Sinema Kuramları. Dost Kitabevi.

CinemaBlend (2020). Why 1917 Director Sam Mendes Broke The One Shot For THAT Scene, https://www.youtube.com/watch?v=G_OYKGGE3g0, Erişim tarihi: 02.08.2020.

Deleuze, G. (2014). Sinema 1: Hareket-Imge. Çev: Soner Özdemir, Norgunk Yayıncılık.

Donnely, M. (2020). Read the Script for Golden Globes Surprise Winner '1917' (EXCLUSIVE), https://variety.com/2020/film/news/1917-screenplay-sam-mendes-full-script-golden-globes-winner-1203458729/, Erişim tarihi: 02.08.2020.

Frazer, B. (2008). www.studiodaily.com/2008/05/sonys-new-f23-debuts-on-speed-racer/ Erişim tarihi: 02.06.2020.

Hitchcock, A. (Yönetmen). (1948). Rope [Sinema Filmi]. ABD.

Hofferman, J., Sarto, D. (2020). The Triumph of Invisibility: The Spectacular Non-Spectacular Effects of '1917', https://www.awn.com/vfxworld/triumph-invisibility-spectacular-non-spectaculareffects-1917, Erişim tarihi: 01.08.2020.

https://books.google.com.tr/books?hl=tr\&lr=\&id=XbirDwAAQBAJ\&oi=fnd\&pg=PT- 
$7 \& d q=$ russian +ark\&ots=sXVApVVord\&sig=CFvodasUcDjoAeF3KJU2JIr-f10\&redir_ esc=y\#v=onepage\&q=russian\%20ark\&f=false ,Erişim tarihi: 24.07.2020.

Inarrutu, G. Alejandro (Yönetmen). (2014). Birdman [Sinema Filmi]. ABD.

Kendricken D. (2013). End of an Era: Fuji Officially Ends Production of Motion Picture Film. https:// nofilmschool.com/2013/04/fuji-ends-production-motion-picture-film\#: :text=Discontinuation\%20 of $\% 20$ Motion\%20Picture\%20Film\%20production\&text=As\%20previously\%20announced\%2C\%20Fujifilm\%20has,Film\%20products\%20by\%20March\%2C\%202013. Erişim tarihi: 14.07.2020.

Lang, B. (2019). How Sam Mendes and Roger Deakins Pulled Off the One-Shot War Epic '1917'. https://variety.com/2019/film/news/sam-mendes-roger-deakins-1917-1203425116/ , Erişim tarihi: 07.08.2020.

Mendes, S. (Yönetmen). (2019). 1917 [Sinema Filmi]. ABD.

Monaco, J. (2001). Bir Film Nasıl Okunur? Çev: Ertan Yılmaz, Oğlak Yayınları.

MPC Film, 1917 VFX Breakdown, (2020). https://www.youtube.com/watch?v=B_llajTMEXI, Erişim Tarihi: 01.08.2020.

Pasolini, P.P. (1972). Plan-Sekans Veya Gerçeğin Semiyolojisi Olarak Film Tartışması. Empirismo Eretico, Çev: Sali Saliji. www.deviantart.com/svevo/art/Plan-Sekans-114519983 Erişim tarihi: 03.06.2020.

Perkins, V. F. (1974). Film as Film. Penguin Books, Middlesex.

Pulver, A. (2019). https://www.theguardian.com/film/2019/oct/13/the-irishman-martin-scorsesedefends-decision-to-go-with-netflix Erişim tarihi: 03.06.2020.

Renee, V. (2015). A Closer Look at the Hidden Editing Techniques Used in 'Birdman', https:// nofilmschool.com/2015/10/a-closer-look-hidden-editing-techniques-in-birdman, Erişim tarihi: 08.08.2020.

Russkiy kovcheg. www.imdb.com/title/tt0318034/technical?ref_=tt_dt_spec Erişim tarihi: 02.06.2020.

Savaş, H. (2019). Film Eleştirisinde Biçim-içcerik Sorunu. Karadeniz Teknik Üniversitesi İletişim Fakültesi Elektronik Dergisi. Cilt:6, Sayı: 17. Temmuz, ss. 18-36.

Schipper, S. (2016). Sebastian Schipper and Laia Costa on "Victoria" | AOL BUILD. https://www. youtube.com/watch?v=3KluPyrqmOY\&t=1571s Erişim tarihi: 20.07.2020.

Schipper, S. (Yönetmen). (2015). Victoria [Sinema Filmi]. Almanya.

Seville Pictures, http://www.nostalghia.com/TheNews/RussianArk_SevillePressNotes.pdf , Erişim Tarihi: 23.07.2020

shotonwhat.com/cameras/sony-hdw-f900-camera Erişim tarihi: 02.06.2020.

Sokurov, A. (2002). To The European Fllm Awards 2002, 19.11.2002, https://web.archive. org/web/20070816133343/http://www.sokurov.spb.ru/island_en/ans_1.html, Erişim Tarihi: 23.07.2020.

Sokurov, A. (Yönetmen). (2001). Russian Ark [Sinema Filmi]. Rusya. 
Taylor, C. (2019). '1917' Is Half Movie, Half Video Game, All Genius, https://mashable.com/ article/1917-movie-review/?europe=true , Erişim tarihi: 07.08.2020.

The Wachowski Brothers (Yönetmen). (2008). Speed Racer. ABD.

Topçu, G. (2008). Görsel Biçem: Hollywood Biçeminin Izinde, ss.137-143, Sinema: Tarih/Kuram/ Eleştiri. Ed: Seçil Büker, Gürhan Topçu. Gazi Üniversitesi Illetişim Fakültesi Basımevi.

Truffaut F. (1987). Hitchcock. Çev: İlyas Hızlı. Afa Yayınları.

Variety, (2014). Variety Artisans: The Seamless Look of 'Birdman', https://www.youtube.com/ watch? $v=X x X W s 74 \mathrm{dKnE}$, Erişim tarihi: 08.08.2020.

Wilfert, P., https://patrickwilfert.com/russian-ark/ ,Erişim tarihi: 23.07.2020.

\section{Extended Abstract}

The aim of this study is to examine how technological equipment and techniques used in cinema affect the use of plan-sequence and its reflections on film language. In the study, the contributions of technological developments in cinema to the application of this technique were revealed through the 1917 film and accordingly, the effects of plansequence on the film style were analyzed with a descriptive method.

By the possibilities offered by the technological developments to the cinema technique, it has been observed that the production of plan-sequence shooting and the films that look like a single plan by combining them have become easier than before. As a result, it has been revealed that films that seem like a single plan can be edited to a certain extent thanks to new techniques and thus the director preserves his control over the film style.

In terms of technological developments, important barriers such as recording time have been overcome thanks to digitalization. Afterwards, the combination of computer generated images and real images has become widespread. Finally, as the equipment becomes more compact, lighter, and also the variety of camera support rigs, the plan-sequence method is limited only by the imagination of the film's creators. Plansequence, which often appears as a "tour de force" in which the director exhibits his talents as "metteur en scene" in mainstream commercial cinema, has an important potential to enrich the film language and to be used to create new layers of meaning.

The ability of the camera to continuously view characters and events without unmotivated movements and to move around the space "without making itself felt" contributes to the creation of the single shot illusion.

1917 emerged as a film that was transformed into a single shot by combining long shots without cutting and plan-sequences unnoticed. Without the need for improvisation, without completely transferring control over the scene to the actor or cameraman, a film that looks like a single shot could be made, and again, nothing was lost from the visual aesthetics of single shot films. Making a one-shot film is about the style of the director of the film, and a debate as to which one is more acceptable in terms of the 
relationship between cinema and reality is open-ended. Combined with the moving camera, this technique creates an alternative film style to the condensed continuity setting and has shown that the point reached by making use of the possibilities of the technique still has the potential to create new narrative forms. 